Universidade de Brasília

Faculdade de Educação

UMA ABORDAGEM SOBRE A RELAÇÃO ENTRE AFETIVIDADE, APRENDIZAGEM E SENTIDO SUBJETIVO DA DEFICIÊNCIA VISUAL: RELATOS DE EXPERIÊNCIAS EM UMA ESCOLA PÚBLICA DO DISTRITO FEDERAL

Débora de Sousa Machado

Brasília - DF 2007 
Débora de Sousa Machado

\section{UMA ABORDAGEM SOBRE A RELAÇÃO ENTRE AFETIVIDADE, APRENDIZAGEM E SENTIDO SUBJETIVO DA DEFICIÊNCIA VISUAL: RELATOS DE EXPERIÊNCIAS EM UMA ESCOLA PÚBLICA DO DISTRITO FEDERAL}

$\begin{array}{llr}\text { Trabalho } & \text { Final de Curso } \\ \text { apresentado como requisito parcial } \\ \text { para obtenção do título de } \\ \text { Licenciado em Pedagogia, à } \\ \text { Comissão Examinadora } \\ \text { Faculdade de da } \\ \text { Universidade de Brasília, sob a } \\ \text { orientação da professora Ms. } \\ \text { Patrícia Neves Raposo. }\end{array}$

Brasília - DF 2007 


\section{UMA ABORDAGEM SOBRE A RELAÇÃO ENTRE AFETIVIDADE, APRENDIZAGEM E SENTIDO SUBJETIVO DA DEFICIÊNCIA VISUAL: RELATOS DE EXPERIÊNCIAS EM UMA ESCOLA PÚBLICA DO DISTRITO FEDERAL}

$\begin{array}{llrr}\text { Trabalho } & \text { Final de Curso } \\ \text { apresentado como requisito parcial } \\ \text { para obtenção do título de } \\ \text { Licenciado em } & \text { Pedagogia, à } \\ \text { Comissão Examinadora } & \text { da } \\ \text { Faculdade de } & \text { Educação da } \\ \text { Universidade de Brasília, sob a } \\ \text { orientação da professora Ms. } \\ \text { Patrícia Neves Raposo. }\end{array}$

\section{COMISSÃO EXAMINADORA}

Prof. Ms. Patrícia Neves Raposo - Orientadora

Faculdade de Educação da Universidade de Brasília

Prof. Dr. Cristiano Alberto Muniz - Examinador

Faculdade de Educação da Universidade de Brasília

Prof. Ms. Bianor Domingues Barra Junior - Examinador

Faculdade de Educação da Universidade de Brasília 
Débora de Sousa Machado

\section{UMA ABORDAGEM SOBRE A RELAÇÃO ENTRE AFETIVIDADE, APRENDIZAGEM E SENTIDO SUBJETIVO DA DEFICIÊNCIA VISUAL: RELATOS DE EXPERIÊNCIAS EM UMA ESCOLA PÚBLICA DO DISTRITO FEDERAL}

\section{COMISSÃO EXAMINADORA}

Prof. Ms. Patrícia Neves Raposo

Faculdade de Educação da Universidade de Brasília

Prof. Dr. Cristiano Alberto Muniz

Faculdade de Educação da Universidade de Brasília

Prof. Ms. Bianor Domingues Barra Junior

Faculdade de Educação da Universidade de Brasília

Brasília - DF

2007 
Aos meus avós, José Elias e Maria das Mercês, que, mesmo diante de inúmeras lutas, nunca desistiram de viver: alegria, humildade, lealdade, amor em ação, perseverança, cumplicidade, união, solidariedade, ousadia e fé. 


\section{AGRADECIMENTOS}

Todas as palavras seriam apenas uma pequena tentativa de expressar a minha gratidão a Ti, Senhor Jesus. Obrigada pelo incondicional amor, pela imensa bondade e sempre presente fidelidade. Obrigada pela salvação que me deste por meio da morte na cruz e porque o Senhor não desiste de me amar. És Tu, Senhor, a razão da minha existência!

A minha mãe, pelo amor, sustento e apoio incomensuráveis. Obrigada por me ensinar a não desistir dos meus sonhos e a perseverar mesmo quando as circunstâncias não são favoráveis. Você é um exemplo de vida!

Ao meu pai, pelo carinho e pelas sábias palavras! Talvez ele não faça idéia disso, mas elas foram decisivas, em muitos momentos, para mim.

Ao Diogo, pelo amor, paciência e cumplicidade.

A minha irmã e amiga, Mariana, pelo suporte e ajuda de sempre... Sempre mesmo! É maravilhoso saber que posso contar contigo!

Aos meus avós, José Elias e Maria das Mercês, que muito me ensinam sobre vida com Deus, amor em ação, coragem e fé.

Aos amigos de infância: Bruna, Juliana, Liane, Luciana, Marília, Patrícia e Thiago Eduardo pelo companheirismo em todos os momentos, pelos sorrisos e lágrimas. Vocês fazem parte deste sonho e se tornaram meus irmãos em tempos de angústia!

Aos amigos que fiz na UnB (aqui prefiro não citar nomes para não correr 0 risco de esquecer alguém).

A equipe do Laboratório de Apoio ao Deficiente Visual. Em especial, Carol que muito me ajudou nessa caminhada.

A minha orientadora e amiga, Patrícia Raposo, por espelhar a vida e me ensinar que o essencial é invisível aos olhos.

Aos professores universitários Albertina Martinez, Bianor Domingues, Cristiano Muniz e Genuíno Bordignon, que me ensinam muito mais do que lições e práticas pedagógicas. Ensinaram-me a amar cada vez mais aquilo que faço e a me dedicar naquilo que acredito.

E a tantos outros familiares, amigos e docentes que, direta ou indiretamente, contribuíram para o meu êxito. 
MACHADO, Débora de Sousa. Uma abordagem sobre a relação entre Afetividade, Aprendizagem e Sentido Subjetivo da Deficiência Visual: Relatos de Experiências em uma Escola Pública do Distrito Federal. Brasília-DF, Universidade de Brasília, Faculdade de Educação (Trabalho Final de Curso), 2007. $70 \mathrm{p}$.

\section{RESUMO}

A inclusão tem destaque cada vez maior no contexto educacional brasileiro. No atual cenário escolar, a inclusão de alunos com necessidades educacionais especiais em classes comuns sinaliza a necessidade de pesquisas sobre o tema. A prática pedagógica não contempla adequadamente a diversidade dos sujeitos e outra perspectiva do professor frente a sua prática e frente às necessidades de aprendizagem de seus alunos representa um desafio a ser enfrentado. O presente trabalho tem como objetivo relatar experiências vivenciadas durante o Projeto 4 do curso de Pedagogia da Universidade de Brasília e aborda a relação entre afetividade, aprendizagem e a constituição de sentido subjetivo sobre a deficiência visual de duas professoras de uma escola pública do Distrito Federal, denominada inclusiva. Compreendemos que a aprendizagem dos alunos com deficiência visual está implicada pelas emoções e afetos produzidos no espaço escolar e pelos sentidos subjetivos constituintes da subjetividade humana em suas dimensões individual e social.

Palavras-chave: afetividade, aluno/professor, deficiência visual, subjetividade. 
MACHADO, Débora de Sousa. Uma abordagem sobre a relação entre Afetividade, Aprendizagem e Sentido Subjetivo da Deficiência Visual: Relatos de Experiências em uma Escola Pública do Distrito Federal. Brasília-DF, Universidade de Brasília, Faculdade de Educação (Trabalho Final de Curso), 2007. $70 \mathrm{p}$.

\begin{abstract}
Inclusion has been getting more space in the educational scenario these days. In the current Brazilian scenario, the inclusion of people who needs special educational attention in common classes is now a reality. Therefore, the teacher's comprehension of his or her practice and of the students' learning needs represents a challenge to be faced. This work has as an objective to acknowledge the experiences got from classrooms and deals with the relation between caring, learning and the constitution of a subjective sense over the visual impairment of two public school teachers in Distrito Federal, in so-called inclusive school. We acknowledge that the learning process of visually impaired students is implied by the emotions and caring produced in the school place and by the subjective senses that constitute the human subjectivity in their social and individual spheres.
\end{abstract}

Key-words: caring, student/teacher, visual impairment, subjectivity 
Educar é acreditar na vida e ter esperança no futuro (...)

Educar é semear com sabedoria e colher com paciência.

Augusto Cury 


\section{SUMÁRIO}

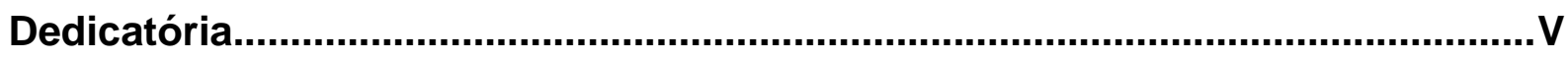

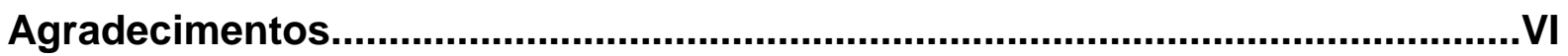

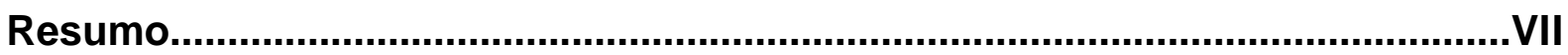

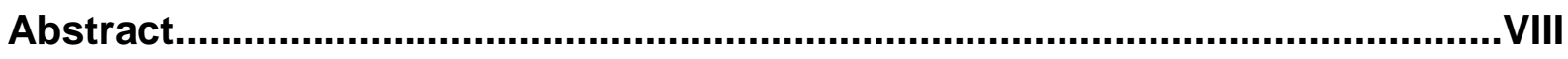

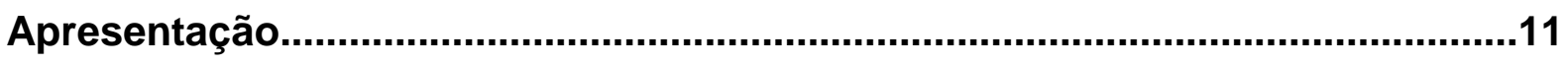

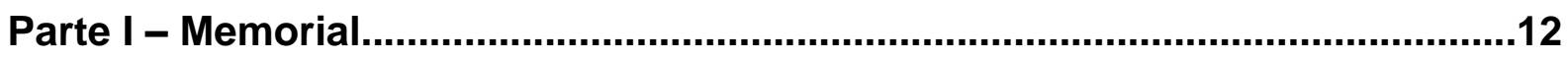

Parte II - Uma abordagem sobre a relação entre Afetividade, Aprendizagem e

Sentido Subjetivo da Deficiência Visual: Relatos de Experiências em uma

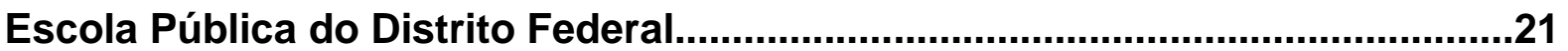

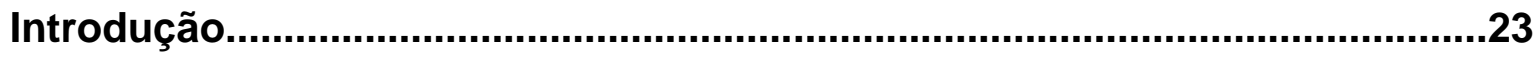

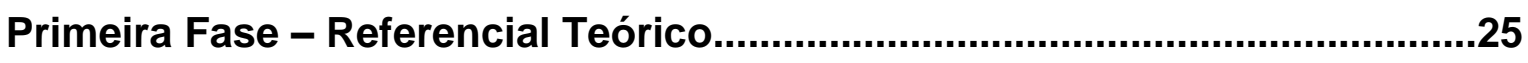

Capítulo 1 - Deficiência Visual: um fenômeno individual $\leftrightarrow$ social.....................26

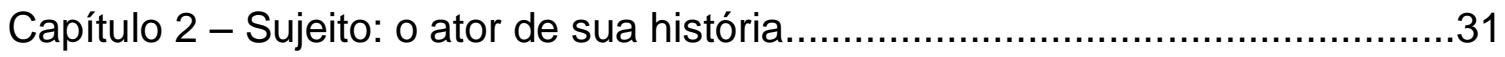

Capítulo 3 - A relação indissolúvel entre afetividade e aprendizagem..................35

Capítulo 4 - As contribuições de González Rey para a compreensão da

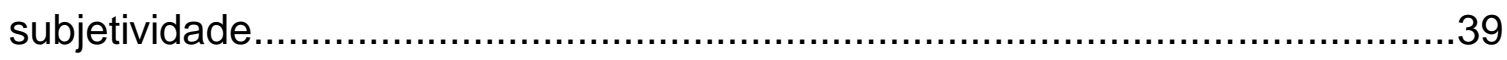

Segunda Fase - Experiências Vivenciadas.....................................................42

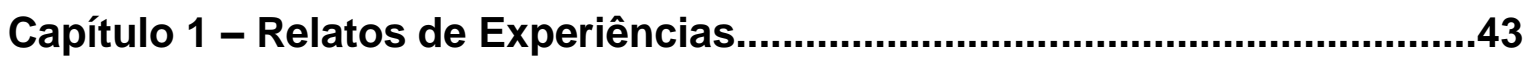

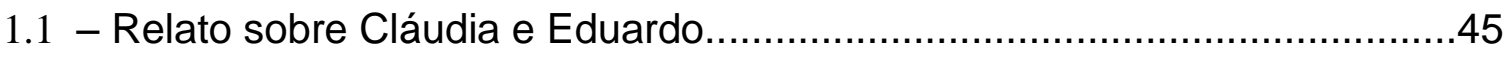

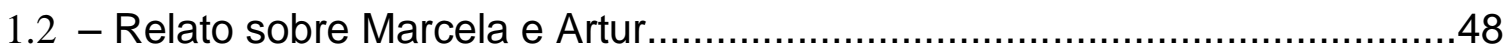

Capítulo 2 - Análise dos Relatos de Experiência.............................................51

Terceira Fase - Considerações Finais.............................................................55

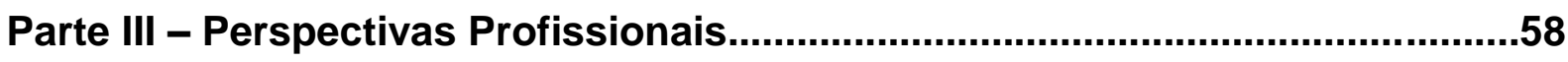

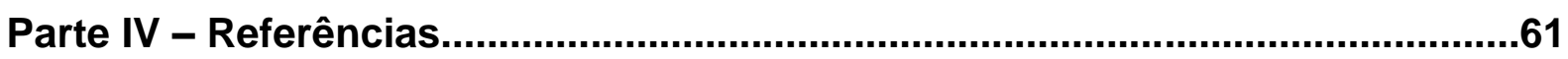

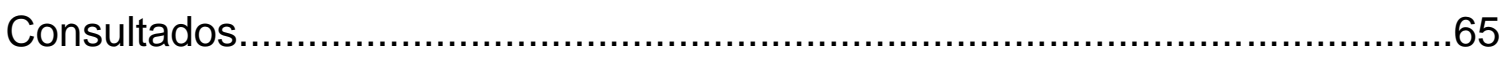




\section{APRESENTAÇÃO}

O presente trabalho monográfico é produção final obrigatória para a conclusão do curso de Pedagogia da Universidade de Brasília (UnB) e constitui-se como um resultado de vivências durante a graduação. Com o título "Uma abordagem sobre relação entre afetividade, aprendizagem e sentido subjetivo da deficiência visual: relatos de experiências em uma escola pública do Distrito Federal", o seu objetivo principal foi compreender que as relações estabelecidas entre professor e aluno e entre os alunos tem impactos na constituição da subjetividade, nas dimensões social e individual.

Para isso, o trabalho foi dividido em partes assim constituídas:

Memorial: reconstitui o itinerário acadêmico por mim percorrido no curso de Pedagogia da Universidade de Brasília, assim como minhas escolhas para os projetos, experiências vivenciadas e aprendizagens nessa trajetória. Destaco, ainda, as disciplinas que foram mais significativas durante a graduação.

Referencial Teórico: apresenta um aprofundamento teórico sobre a deficiência visual, o sujeito, a afetividade, a subjetividade nas dimensões social e individual.

Experiências Vivenciadas: constitui-se em relatos de experiências vivenciadas em duas turmas de uma mesma série de escola pública do Distrito Federal. Apresenta, ainda, análises dessas experiências que articulam a prática das professoras com a teoria apresentada no Referencial Teórico.

Perspectiva Profissional: é uma reflexão sobre minha perspectiva em relação às vivências e aprendizagens durante a graduação, apresentando o projeto de vida profissional. 
Parte I

MEMORIAL 
Nada a temer senão o correr da luta Nada a fazer senão esquecer o medo Abrir o peito à força numa procura Fugir às armadilhas da mata escura Longe se vai sonhando demais... 


\section{MEMORIAL}

Foi preciso muita coragem para chegar onde cheguei. Tive que enfrentar muitos obstáculos, correr contra uma correnteza, disputar uma vaga com tantos outros milhares. Pensei em desistir... Mas, por que eu desistiria se eu tinha uma meta a cumprir, um alvo a alcançar? Eu precisava provar para mim mesmo que era capaz. Fui deixando, aos poucos, muitos para trás. E, finalmente, consegui chegar ao meu objetivo. Só eu consegui isso... VIVA: eu sou um espermatozóide de sucesso!

Tudo era escuro, eu nada conseguia enxergar. Era quentinho e aconchegante. Aos poucos, com o passar do tempo, foi ficando apertado. Meus pais já tinham escolhido meu nome: se fosse menino, Rafael; se fosse menina, Débora. Eles já tinham uma filha de 2 anos, Mariana, quando minha mãe engravidou de mim. Eu estava muito bem no útero da minha mãe, mas já estava chegando à hora de sair dali. Cada dia aparecia algo diferente em mim e minha mãe já tinha dificuldades para dormir, porque eu me mexia demais.

Enquanto o Brasil chorava a morte de Tancredo Neves, em 21 de abril de 1985, meus pais estavam aguardando ansiosos pela minha chegada. Nasci quatro dias depois, em Brasília.

Muitos anos se passaram... Hoje, 22 anos depois, vejo que alcancei muitos objetivos... E sei que ainda há muitos outros objetivos a alcançar e estou batalhando para isso.

Destaco que para chegar hoje aqui algumas pessoas foram essenciais em todos os momentos. São elas:

- Jesus é o dono da minha vida, meu amado Senhor, a quem eu nasci para render graças e adorar. Ele me amou (e ama) a ponto de morrer em meu lugar para que, hoje, eu tivesse vida e vida em abundância. Aprendo muito com o apóstolo Paulo em suas palavras nas Escrituras Sagradas que diz "eu estou bem certo de que nem a morte, nem a vida, nem os anjos, nem os principados, nem as coisas do presente, nem do porvir, nem os poderes, nem a altura, nem a profundidade, nem qualquer outra criatura poderá separar-nos do amor de Deus que está em Cristo 
Jesus, nosso Senhor" (Romanos 8:38-39). Realmente, nada pode nos separar desse amor. Jesus Cristo é o exemplo supremo do amor!

- Minha família que me ensina cada dia mais sobre todos os aspectos que cercam a minha vida e que, apesar de muitas vezes não concordarem comigo, nunca estiveram longe de mim. Em especial, minha mãe que, diariamente, me ensina a ser uma pessoa mais justa, mais agradável e mais amável. Ela é quem merece todo o mérito de quem eu sou e vier a ser...

- Meus irmãos que pude escolher, meus amigos, poucos, todavia com excelência na irmandade, na fraternidade, no companheirismo, na lealdade, enfim... na amizade! Eles se tornaram meus irmãos na hora da angústia e aflição!

No segundo semestre do ano de 2003, fui aprovada no vestibular da Universidade de Brasília para o curso de Pedagogia. Desde 1998, eu já tinha escolhido qual curso fazer na universidade. Além da Pedagogia, pensei nos cursos de Astronomia, Geografia, Letras Português, Psicologia e Fonoaudiologia. Optei pela Pedagogia, por ser a área que mais me identificava e, ao final do curso, posso afirmar que acertei na escolha! $E$, ainda pretendo cursar Psicologia. $E$ isso não é um plano para um futuro distante.

Fiquei muito feliz com esse momento vivido. A aprovação no vestibular foi uma imensa alegria. Pude partilhar com minha família e amigos essa primeira parte da vitória (a segunda parte: é me formar)!

Confesso que a minha primeira impressão da Universidade foi chocante. Em algumas disciplinas, os alunos podiam entrar e sair da sala de aula quando quisessem. Como estudante, era permitido expor minhas idéias, pensamentos, dificuldades e principalmente, eu podia discordar! Coisas que nunca tinha vivenciado antes em sala de aula, porque estudei em uma escola conteudista e tradicional que visava apenas a aprovação no vestibular e que impedia, quase sempre, a exposição das idéias, pensamentos, críticas e ações dos alunos.

Antes, o currículo do curso de Pedagogia da Universidade de Brasília era divido em habilitações que discriminava a(s) área(s) que o licenciado poderia atuar. Dessa maneira, o aluno do curso de Pedagogia podia escolher uma ou duas habilitações entre as ofertadas - Magistério, Orientação Educacional e Educação Especial. 
A proposta do atual currículo envolve a atuação do pedagogo como um ser amplo no qual o educador é capaz de atuar em diversas áreas, espaços e situações educativas, visto que está habilitado para a atuação nas áreas de: Educação Especial, Magistério. Administração Escolar e Orientação Educacional e Vocacional/Profissional.

No segundo semestre, já em 2004, cursei uma disciplina - obrigatória para o currículo do curso de Pedagogia - chamada O Educando com Necessidades Educacionais Especiais com a professora (hoje, minha orientadora) Patrícia Neves Raposo. Essa disciplina fez diferença na minha vida. Não só como estudante, mas como pessoa e como profissional. A professora, além de fundamentar toda a historicidade da deficiência, ainda relatava fatos que vivencia como deficiente visual. Ela sabia e vivia o que estava falando!

Nesse mesmo semestre, cursei a disciplina Organização da Educação Brasileira lecionada pelo professor Genuíno Bordignon. Ele realmente acredita em uma educação emancipadora e contagiou os alunos na esperança de dias melhores para a Educação e para o Brasil, de aplicação das leis educacionais, de compromisso e de afeto. E ele sempre nos lembrava da expressão de Albert Einstein diz que "educação é o que sobra quando se esqueceu tudo o que se aprendeu na escola". Lembro-me com carinho de alguém que nos motivava em todas as aulas a fazer diferença nos ambientes onde estivermos.

No semestre seguinte, comecei o Projeto 3, na área de Orientação Vocacional. Tive como professoras: Patrícia Lima Tôrres e Esther Mendes Ferreira Moreira. Fiz pesquisa de campo em várias escolas do Distrito Federal (DF). Eu escolhi o projeto tendo a certeza, naquela época, de que era a área que eu queria seguir. Foi muito interessante a pesquisa realizada porque pudemos compreender como é a orientação vocacional nas escolas do DF. Essa pesquisa nos abriu a possibilidade de apresentação da mesma no I Congresso Latino-Americano de Orientação Profissional da Associação Brasileira de Orientação Profissional e no VIII Simpósio Brasília de Orientação Vocacional \& Ocupacional Internacional de Orientação Vocacional que foi realizado este ano (2007). Além disso, ramificou-se e a partir dela, várias outras pesquisas que se desenrolavam nas outras fases do projeto. O que eu não esperava (ou talvez, sim) era de que com a monitoria da disciplina O Educando com Necessidades Educacionais Especiais, a questão da Educação Inclusiva viesse a chamar mais atenção e mais inquietação para mim. 
$\mathrm{Na}$ outra fase do Projeto 3, corri para o lado da Psicologia. Desenvolvi, juntamente com a professora Teresa Cristina Siqueira Cerqueira e demais colegas, uma pesquisa com alunos e professores universitários sobre a Representação Social da Escuta Sensível. Foi muito interessante esse lado da Psicologia Social, porque trabalhar com pessoas é o que eu gosto de fazer. Fomos muitas vezes repreendidos pelos nossos entrevistados, porque entramos em questões pessoais da prática do professor e da postura do aluno. Chegamos a determinadas conclusões que ainda precisam ser revistas para futuramente serem publicada. Bem, isso foi o que a professora nos disse.

Finalmente, na última fase do Projeto 3 , fiz filosofia. A professora Luciana de Mello Gomide Foina ofereceu um projeto sobre Filosofia no Cinema muito interessante porque estamos acostumados (aliás, eu estava acostumada) a simplesmente assistir um filme e quando terminasse, também acabava por ali qualquer discussão a respeito dele. Além dos filmes serem escolhidos a dedo, os filmes nos levavam a reflexões, provocações e sentimentos. Éramos desafiados a contar nossa inquietação e a discutir, fundamentados nos autores que estudamos em Filosofia da Educação, nossa vida cotidiana e os fatos inesperados que ocorrem a todos os momentos nela.

Em 2005, fiz o curso para aprender o Sistema Braille. O curso foi lecionado pelo LDV - Laboratório de Apoio ao Deficiente Visual - e aberto pela Escola de Extensão da UnB. O curso me abriu novos horizontes e me ajudou no Projeto 4, sendo que na época em que eu fiz o curso, eu não sabia que iria me ser tão útil. Em setembro desse mesmo ano, fui selecionada como bolsista para o LDV. O objetivo do LDV é proporcionar apoio acadêmico aos estudantes com deficiência visual tanto na UnB como na comunidade. São adaptados materiais em braille, ampliados ou digitalizados. Assiste alunos deficientes visuais, alunos-tutores e também aos professores, além de oferecer consultoria sobre o Sistema Braille e orientação.

No ano de 2006, fiz as duas fases do Projeto 4 com o professor Cristiano Alberto Muniz na $(\mathrm{Re})$ Educação Matemática. Trabalhamos muito na questão da mediação e a necessidade do outro no desenvolvimento humano e, especificamente, para a formação do Conhecimento Matemático. Durante o ano, estagiei em duas classes de primeira série em uma Escola Classe, pelo professor indicada, localizada na Asa Norte - Brasília, Distrito Federal. 
Em uma turma, pude estar durante mais tempo e o trabalho desenvolvido e proposto pelo professor, devido a isso, foi positivo e concluído. Em outra turma, como já havia outra estagiária, estive em momentos bastante significativos embora em um número menor do que na primeira turma que mencionei.

O Projeto 4 representa, segundo suas diretrizes, um momento privilegiado de constituição da identidade do profissional da educação por meio da sua imersão nas práticas educativas que ocorrem no contexto formal. Dessa forma, o estágio teve como objetivo proporcionar momentos ímpares na minha formação enquanto educadora, tendo uma articulação com a teoria estudada no segmento do curso.

As duzentos e quarenta horas (sendo cento e vinte horas em cada fase) de prática docente, obrigatórias para conclusão do Projeto 4, foram cumpridas da seguinte maneira: cento e oitenta horas (noventa horas em cada fase) em uma Escola Classe e sessenta horas (trinta horas em cada fase) para planejamento das atividades.

Tive várias experiências nessa escola e sou eternamente grata a tudo que passei no decorrer do estágio. Nessa escola, alunos com necessidades especiais estavam inseridos nas classes diante da proposta da inclusão. Apoiei alguns desses: dois com deficiência visual e um com deficiência física. Adaptei material e, principalmente, fui um canal de inserção social. Mediei não só na construção do conhecimento, mas nas vivências e atividades em sala e no pátio da escola. Procurei mostrar aos demais colegas da sala, que, além da deficiência, eles têm sentimentos, vontades, desejos, anseios, raiva, como qualquer ser humano. Foi muito interessante trabalhar esses valores de justiça, eqüidade e amizade com eles.

Não poderia me esquecer das professoras Albertina Mitjáns Martinez, Elizabeth Danziato Rego Lima e Vera Margarida Lessa Catalão e do professor Bianor Domingues Barra Júnior.

Com a Albertina, cursei a disciplina Criatividade e Inovação na Educação no segundo semestre letivo do ano de 2006. Foi uma experiência maravilhosa e uma quebra de muitos paradigmas ligados à criatividade. Acredito que essa disciplina deve ser obrigatória para o curso de Pedagogia. Principalmente porque se pensa que a criatividade se dá apenas em algumas pessoas e em determinados espaços. E em nossas atividades propostas na disciplina, vimos que é muito além disso e que se pode desenvolver em qualquer área da atividade humana de modo a representar algum tipo de novidade e que resulta valiosamente de alguma forma. 
Com a Beth (ela nos permite a chamá-la assim) cursei duas disciplinas na área de tecnologia na Educação. São elas: Educação a Distância e Pesquisa na Educação a Distância. É uma área que está se desenvolvendo rapidamente nos últimos anos e de acordo com as tendências do mercado se desenvolverá mais e mais rápido. Como existem mitos sobre Educação a Distancia! Um curso a distancia exige (ainda mais do que o presencial) participação, dinamismo, motivação e orientação. A educação a distância surgiu como uma modalidade de ensino e não pode ser vista como a solução dos problemas educacionais e dos planos governamentais.

Cursei Fundamentos da Educação Ambiental com a Verinha (ela também nos permitia chamá-la assim) que nos ensinou que a luz não esconde a beleza da noite, apenas ilumina o caminho... Quão nobre é essa professora! Ecologia, meio ambiente, reciclagem são termos que estão diariamente nas notícias da televisão, dos jornais e da internet. Não pára por aí, muitas são as palavras e expressões referentes ao meio ambiente em si, no que estamos fazendo dele e com ele e como ele tem reagido a essas ações humanas. Aprendi valores como a sustentabilidade e a transversalidade e esses passarei aos meus educandos, amigos, familiares e a todos aqueles que estão a minha volta.

A disciplina lecionada pelo professor Bianor foi Avaliação Educacional da pessoa com Necessidades Educacionais Especiais. Éramos poucos alunos em sala e esse fato permitiu que tivéssemos um grupo participativo, crítico e questionador. Muitas discussões foram levantadas e muitos aprendizados tivemos uns com os outros. A aula era um especial momento de aprendizagem colaborativa. Em uma das atividades propostas pelo professor, além de termos trabalhado muita teoria, fizemos um estudo de caso. Para essa atividade, procuramos casos reais nos quais observamos a pessoa deficiente em ambientes escolares, religiosos ou familiares e pudemos perceber que, até hoje, infelizmente, muitos professores e, para a minha surpresa, muitos pais avaliam a deficiência por si só, sem considerar o desenvolvimento da pessoa com deficiência. Muitos ainda ficam presos ao diagnóstico ou à espera do mesmo. Algumas escolas, ainda, são intituladas inclusivas e não fazem sequer um trabalho inclusivo com as crianças com necessidades especiais. Essa disciplina foi fundamental para o aprimoramento teórico e, para mim, principalmente, para discussões fundamentadas principalmente naquilo que acreditamos: a inclusão, na verdade, é um ato pessoal. 
Em 2007, comecei a trabalhar uma classe de nível três (antigo Jardim II) de uma escola particular de Brasília. Cada dia descubro que a teoria nem sempre tem razão e que a diferença sou eu quem tem que fazer na vida nos meus alunos, dessa maneira, minha preocupação com o desenvolvimento de cada um deles aumenta e o quando a minha preocupação em relação aos meus alunos se acabar é porque a educação já não faz mais sentido para mim.

Hoje, sei que minha história está em andamento... Tenho aprendido muitas coisas novas e sinto-me, cada vez mais, apaixonada pela vida. E sei que apesar das circunstancias, Deus está sempre comigo. Sou muito feliz. Sinto que a minha vida é um grande aprendizado, uma grande vitória. Não que tudo seja um mar de rosas e que não haja barreiras e obstáculos... Mas, principalmente, pelo amor que sinto e pela imensa vontade de viver que tenho. Isso basta! 
Parte II

UMA ABORDAGEM SOBRE A RELAÇÃO ENTRE AFETIVIDADE, APRENDIZAGEM E SENTIDO SUBJETIVO DA DEFICIÊNCIA VISUAL: RELATOS DE EXPERIÊNCIAS EM UMA ESCOLA PÚBLICA DO DISTRITO FEDERAL 
Não sei como preparar o educador. Talvez porque isso não seja nem necessário, nem possível... É necessário acordá-lo. E aí aprenderemos que educadores não se extinguiram como tropeiros e caixeiros. Porque, talvez, nem tropeiros, nem caixeiros tenham desaparecido, mas permaneçam como memórias de um passado que está mais próximo do nosso futuro que o ontem.

Basta que os chamemos do seu sono, por um ato de amor e coragem.

E talvez, acordados, repetirão o milagre de instauração de novos mundos. 


\section{INTRODUÇÃO}

O mundo está em constante mudança. Nada é definitivo. Muito se pensa a respeito de melhorar a qualidade de vida e, principalmente, a aparência das pessoas. Nunca se viveu em um mundo com tantos recursos: telecomunicações celulares, computadores de última geração, internet, televisão digital - cirurgias plásticas, 'botox', silicones; ao mesmo tempo em que se preocupa muito com a aparência, pouco se preocupa com a saúde, afinal, tornam-se moda o tabaco, o álcool, as drogas e os 'fast-food' todos os dias. O mundo atual é um paradoxo entre um tempo de liberdade sem precedentes e um tempo de escravos e escravizados, principalmente pela manipulação da imagem instrumentalizada pela mídia. Um paradoxo entre a vida em sociedade e o individualismo.

Tanto se fala em melhorar a vida, porém essa mudança é válida apenas para o eu. Não se pensa em contribuir para que o outro também tenha uma melhor qualidade de vida. Ao mesmo tempo em que devemos viver em comunidade, ou seja, comum unidade, e sociedade, muito se fala, também, em individualismo, de maneira que o outro se torna um ser estranho para o eu.

O discurso de inclusão escolar não é tão recente como se parece ser, nem tampouco se tornou exaustivo. São muitos os estudos relacionados ao tema da inclusão e muitas experiências estão sendo realizadas, tendo em vista a melhoria da qualidade da educação e do acesso e permanência de todos na escola. Baseandose nisso, o presente trabalho tem como principal objetivo apontar aspectos das relações estabelecidas entre professor-aluno e aluno-aluno e os impactos que podem representar na constituição da subjetividade dos sujeitos participantes do espaço escolar. Não nos propusemos a compreender a subjetividade dos sujeitos e o sentido subjetivo relacionado à deficiência visual. No entanto, buscamos destacar alguns aspectos significativos na relação professor-aluno que identificam elementos importantes no processo de aprendizagem dos alunos com deficiência visual implicados nos nossos relatos.

Para isso, o trabalho foi dividido em fases assim constituídas:

O Referencial Teórico está dividido em quatro capítulos. No primeiro capítulo é apresentada a deficiência como um fenômeno individual e social e uma contextualização histórica sobre o tema nas civilizações antigas. Aborda também a 
deficiência visual que representa nosso grupo de estudo e discussão. O segundo capítulo aborda a concepção de sujeito nas teorias de Vigotski, González Rey e Wallon em razão das abordagens desenvolvidas por tais teóricos em relação ao sujeito, a subjetividade, o eu e o outro. $O$ terceiro capítulo faz considerações a cerca da afetividade e a importante relação que o outro tem no desenvolvimento humano E, a partir dessa relação, como os vínculos afetivos são estabelecidos. O quarto capítulo apresenta as contribuições da teoria da subjetividade de González Rey para a compreensão dos amplos e complexos processos da psique humana nas dimensões individual e social.

Experiências Vivenciadas constituem-se em dois capítulos: o primeiro capítulo, traz os Relatos de Experiências, que apresentam nossas observações sobre atitudes e atividades desenvolvidas por duas professoras para com os alunos deficientes visuais; o segundo capítulo faz uma análise dos relatos de experiência que articulam a prática das professoras com a teoria apresentada no trabalho.

Apresentamos as Considerações Finais como parte das contribuições que esse trabalho aponta para as idéias relacionadas à prática educativa e da importância da criticidade frente às teorias e as posturas que, como educadores, adotaremos em nossas atividades, tendo em vista que a escola é um espaço de construção de sentidos e significados. 


\section{PARTE II}

PRIMEIRA FASE

REFERENCIAL TEÓRICO 


\section{CAPÍTULO 1 - DEFICIÊNCIA VISUAL: UM FENÔMENO INDIVIDUAL $\leftrightarrow$ SOCIAL}

Atualmente está na moda a discussão da inclusão escolar, mas anteriormente quase não se pensava a respeito dela. A sociedade, em geral, sempre teve uma atitude negativa, ou seja, de exclusão em relação à pessoa com necessidade especial. Muitos pensavam que as pessoas com necessidades educacionais especiais $^{1}$ não precisavam aprender, formar-se ou informar-se. Há muitos preconceitos que geram choques na sociedade a respeito das pessoas com deficiência, particularmente, pois as pessoas, em geral, não conseguem enxergar além da deficiência do outro. Isso acontece porque "a 'deficiência' é o que mais realça, visto o impacto e o desconforto que gera no outro" (Ferreira e Guimarães, 2003, p. 21).

Como reconhecida pelas Diretrizes Nacionais para a Educação Especial na Educação Básica, a deficiência é um fenômeno humano, individual e social com influências históricas e culturais em sua conjuntura. As comunidades também apresentam uma parcela de contribuição na representação social da deficiência, ou seja, os fatores políticos, éticos e econômicos são determinantes na construção cultural do que é a deficiência. Porém essa representação social da deficiência como fenômeno multideterminado é algo relativamente recente. Os registros da História apontam para São Tomás de Aquino como o precursor da idéia de deficiência como um fenômeno humano, natural e involuntário. Nas Idades Antiga e Média, principalmente, toda pessoa com deficiência era absolutamente rejeitada e discriminada desde o nascimento, não lhes atribuindo o direito de viver. Até 0 princípio da Era Cristã era comum a prática de infanticídio para com pessoas deficientes, que eram afogadas ou lançadas em abismo. Os primeiros Estados a admitirem a existência de pessoas com deficiência em seu meio, deixavam-nos à margem da sociedade. Quando mulher, era abandonada e servia à prática da

\footnotetext{
${ }^{1}$ De acordo com o Artigo 5ำ da Resolução no 2 de 11 de setembro de 2001 do CNE/CEB, pessoas com necessidades educacionais especiais são aquelas que durante o processo educacional apresentam: dificuldades de aprendizagens ou limitações no processo de desenvolvimento que dificultam o acompanhamento das atividades; com dificuldades de comunicação e sinalização diferenciadas dos outros alunos, que necessitem de linguagens e códigos diferenciados que se apliquem a eles; e com altas habilidades.
} 
prostituição; quando homem, escondido e descartado, uma vez que não era considerado apto ao serviço do Estado e à defesa digna do seu exército.

As pessoas com deficiência visual compõem o grupo anteriormente abordado e representa nosso objeto de discussão e análise. O termo deficiência visual, de acordo com o Decreto ㄲo 5.296 de 02 de dezembro de 2004, Capítulo II, Artigo 5, Inciso $1^{\circ}$, refere-se à deficiência visual como

cegueira, na qual a acuidade visual é igual ou menor que 0,05 no melhor olho, com a melhor correção óptica; a baixa visão, que significa acuidade visual entre 0,3 e 0,05 no melhor olho, com a melhor correção óptica; os casos nos quais a somatória da medida do campo visual em ambos os olhos for igual ou menor que 60ㅜ ou a ocorrência simultânea de quaisquer das condições anteriores. ${ }^{2}$

A deficiência visual é uma situação irreversível de diminuição, seja total ou parcial, da visão mesmo após tratamento clínico e/ou cirúrgico e uso de lentes corretivas - óculos convencionais, lupas e lentes de contato. Os fatores que levam a tal situação podem ser congênitos ou hereditários. A diminuição da resposta visual é classificada de acordo com a intensidade da perda, total ou parcial, da visão, podendo ser:

- Leve;

- Moderada;

- Severa ou profunda (baixa visão);

- Ausência total (cegueira).

Em relação ao campo visual, temos o comprometimento da visão central ou da visão periférica. As pessoas com deficiência visual moderada estão possibilitadas de realizar tarefas visuais com o uso de ajuda e iluminação adequada de acordo com suas necessidades. As pessoas com deficiência visual severa ou profunda encontram dificuldades na realização de atividades visuais grosseiras e estão impossibilitadas de realizar tarefas que requeiram visão de detalhes e exatidão, e

\footnotetext{
${ }^{2}$ Os números decimais referem-se à porcentagem.
} 
requerem adequação de tempo, ajudas e modificações, que viabilizam o acesso à informação.

De acordo com Martín e Bueno (2003), as pessoas com baixa visão têm dificuldades de perceber aspectos visuais relacionados com: traços desproporcionais no espaço, representações tridimensionais, formas compostas, profundidade, movimento, objetos ou materiais situados sobre fundos similares, objetos com pouca luz, detalhes distintivos nas formas e centros das figuras. As pessoas cegas são aquelas que apresentam desde ausência total de visão até a perda da percepção luminosa.

Segundo a OMS - Organização Mundial de Saúde (apud Felippe, 2003),

mais de 180 milhões de pessoas no mundo têm deficiência visual. Dessas, 45 milhões são cegas e 135 milhões têm baixa visão. A cada ano, 2 milhões de novos casos de cegueira são registrados, sendo que $80 \%$ correspondem a indivíduos com mais de 60 anos de idade. No Brasil existem hoje 16,5 milhões de deficientes visuais. Eles fazem parte do grupo mais numeroso entre os portadores de algum tipo de deficiência. Representam $48 \%$ do total, dos quais 160 mil deles nada enxergam e os demais apresentam algum grau de perda visual (Censo Demográfico do IBGE, de 2000).

Isso significa que cerca de $1 \%$ (um por cento) da população mundial apresenta algum grau de deficiência visual. Sendo que mais de 90\% (noventa por cento) desse número encontram-se nos países em desenvolvimento. Há que se considerar que nos países subdesenvolvidos e em desenvolvimento, as principais causas são nutricionais, traumáticas e doenças infecciosas. Já nos países desenvolvidos, as causas são genéticas e degenerativas. Além disso, as causas podem ser divididas também em: congênitas ou adquiridas. As causas congênitas são inatas, aquelas com as quais o sujeito já nasce, tais como: malformações oculares, glaucoma congênito, catarata congênita e cegueira. As causas adquiridas são aquelas que o sujeito adquire ao longo da vida, tais como: traumas oculares, catarata, glaucoma, alterações retinianas relacionadas à hipertensão arterial ou diabetes, podendo levar à cegueira. 
Bebês podem nascer sem visão e outras pessoas podem tornar-se deficientes visuais em qualquer fase da vida. A perda de visão pode ocorrer repentinamente em um acidente ou doença súbita, ou tão gradativamente que a pessoa atingida demore a tomar consciência do que está acontecendo. Existem alguns sinais indicativos da presença da deficiência visual na criança, entre eles: desvio de um dos olhos, não seguimento visual de objetos, não reconhecimento visual de familiares, baixo aproveitamento escolar, atraso de desenvolvimento. É importante ressaltar que tanto em crianças quanto nos adultos, algumas mudanças são notáveis. Essas mudanças podem ser: vermelhidão, mancha branca nos olhos, dor, lacrimejamento, flashes, esbarrões e tropeços em objetos e móveis - causado pela redução do campo visual.

Segundo Ruiz, Molina, Bueno \& Lara (2003),

o funcionamento visual, considerado como a maior ou menor capacidade da criança usar seu resíduo de visão na realização de tarefas cotidianas está diretamente relacionado às características físicas e mentais do indivíduo, aos fatores ambientais com os quais atua cotidianamente e à motivação que apresenta para realizar tarefas visuais. (p. 45)

Dessa forma, quanto mais experiências visuais a pessoa tiver, mais condutos cerebrais serão estimulados, acumulando imagens visuais que em determinadas situações são recordadas. Quando um vidente - termo usado para as pessoas que enxergam - fala nuvem, por exemplo, a pessoa que tem ou teve um resíduo visual já associa à nuvem que vemos no céu, contudo, uma pessoa que não tem ou teve um resíduo não fará tal associação. Neste sentido, podemos considerar que os dois sentidos mais importantes para o cego são: audição, que adquire, no cego, funções telereceptoras; e tato, que permite ao cego o conhecimento sensorial dos objetos animados e inanimados que constituem o ambiente.

A sociedade em geral considera o cego como uma pessoa amarga, condenada e indefesa. Uma vida de cegueira é considerada uma vida de escuridão e horror, o que, em alguns casos, desperta atitudes de piedade e, às vezes, generosidade. Tal comportamento exerce poderosa influência sobre o cego, sobre sua auto-imagem e sobre o seu papel social. Isso é mais prejudicial que benéfico 
para ele, e mais nocivo para sua personalidade que qualquer outro elemento na situação social. Normalmente, o vidente percebe o cego como uma pessoa incompetente e inativa, incapaz de produzir. Concordando com Raposo (2004, em sala de aula), a questão não é fazer da cegueira o problema da vida de um cego, mas um dos problemas. Vendo dessa forma, alguns paradigmas são quebrados e a própria pessoa cega começa a aceitar-se como tal. Nós, videntes, devemos tratá-la como um sujeito singular. Quando as pessoas videntes as tratam como seres inúteis e as fazem sentir-se isolados da sociedade, os cegos acabam por sentir-se mal, ainda mais quando quem o considera desse modo são componentes significativos para ele: pais, irmãos, amigos, professores. A questão passa, então, a ser social. Somos todos singulares, portanto, não há o que comparar.

Inferioridade, insegurança e solidão são sentimentos perante os quais muitos cegos reagem por meio da fantasia e evadem da realidade para criar um mundo imaginário e inexistente, afastando do meio social e buscando isolar-se do mundo real. Em se tratando do emocional e de relacionamentos sociais, o cego deve considerar alguns pontos principais: a aceitação da própria imagem; aceitação das limitações físicas derivadas da sua deficiência visual e, ao mesmo tempo, ser aceito pelos demais; promover uma reflexão sobre a família e na família, que influirá na formação da sua auto-estima e promover uma reflexão por parte dos colegas do grupo social - colegas de classe, da igreja, da rua, parentes - propiciam relações harmoniosas em meio às diferenças interpessoais, assim como o respeito para com os colegas.

A família tem grande importância para a constituição do aspecto psicossocial necessário para o desenvolvimento afetivo. $O$ apoio dos pais desde o nascimento com o objetivo de socializar evita o isolamento do seu ambiente. $O$ envolvimento de todos os familiares no processo de formação e atuação precoce com a criança é primordial para o êxito na educação.

É importante ressaltar que a pessoa com deficiência deve estar inserida na sociedade de maneira que a modifica e por ela é modificada. Com base nessa perspectiva de relação recíproca entre social e individual, nos propusemos a ir ao encontro com o sujeito que será fundamentado teoricamente no próximo capítulo. 


\section{CAPÍTULO 2 - SUJEITO: O ATOR DE SUA HISTÓRIA}

Nesse trabalho, partimos de perspectivas teóricas de Vigotski, González Rey e Wallon em razão das abordagens desenvolvidas em relação ao sujeito, a subjetividade, o eu e o outro.

A educação ocorre em um dado contexto de maneira que ele a influencia e dela sofre influências, ou seja, um contínuo movimento dialético. Desejável é que a educação seja um canal de mudança política, histórica, social, cultural e econômica. Para que isso ocorra é necessário que haja uma transformação no foco educacional: da concepção de educação como um mero ato de reprodução e transmissão do conhecimento para a construção e constituição do indivíduo como sujeito ativo e interativo. Desse modo, é por meio das relações interativas que o conhecimento, as funções e os papéis sociais são constituídos, além de permitir a formação de conhecimentos e da própria consciência. E são nessas relações interativas estabelecidas que transformamos e somos transformados contínua e simultaneamente (Tacca, 2004).

Na perspectiva histórico-cultural há dois aspectos da teoria marxista que são fundamentais para a compreensão da proposta em que estamos trabalhando: o cultural e o sócio-histórico. O cultural ocorre por meio da forma como a sociedade se organiza, de como o conhecimento é perpassado usando instrumentos simbólicos e concretos, ou seja, a transmissão da própria cultura. O sócio-histórico remete-se à vida em sociedade e ao aperfeiçoamento dos instrumentos simbólicos e físicos utilizados na cultura. Não há como dissociar o cultural do sócio-histórico, visto que acreditamos em sua relação dialética.

Segundo Urt (2000), a nossa história enquanto indivíduos é a própria história da humanidade e que as transformações que sofremos são decorrentes das transformações sofridas pela sociedade. A autora ainda ressalta que não se deve ter dúvidas a respeito da nossa existência como sujeitos porque nossos pensamentos, afetos, desejos e emoções são próprios de cada indivíduo. Todavia não se pode considerar que essa é maneira universal e linear da constituição do sujeito. Ao contrário, somos constituídos em decorrência das transformações sociais sofridas historicamente. 
Do mesmo modo, o sujeito, para Vigotski (1983), não é apenas ativo. É também interativo e se constitui enquanto tal a partir de dois momentos de desenvolvimento essenciais: a dimensão interpsíquica e a dimensão intrapsíquica. A interpsíquica é caracterizada pelas interações no nível social e a intrapsíquica caracteriza-se por transformações individuais, possibilitando a reelaboração e a releitura das transformações ocorridas socialmente. O autor ainda destaca que o desenvolvimento do sujeito se dá em caráter progressivo e com a unificação afetointelecto e, além disso, destaca que as pessoas se caracterizam pela personalidade, o que as faz sujeitos singulares. Ressaltando a unidade afeto-intelecto, Vigotski considera a interdependência do afetivo e do intelectual na constituição do sujeito.

González Rey (2003), amparado à teoria de Vigotski, traz a concepção de sujeito como uma categoria do ser humano que é constituído social e individualmente em um processo dialético que produz sentido subjetivo, sendo que no decorrer de sua vida vão se desenvolvendo a emoção, os significados e as necessidades. $O$ autor enfatiza que

o sujeito representa um momento de subjetivação dentro dos espaços sociais em que atua e, simultaneamente, é constituído dentro desses espaços na própria processualidade que caracteriza sua ação dentro deles, a qual está sempre comprometida direta ou indiretamente com inúmeros sistemas de relação (GONZÁLEZ REY, 2003, p. 235).

O sujeito não é formado pelos acontecimentos e situações que ocorre em sua vida individualmente e por si só. Contrapondo-se a isso, o sujeito se constitui a partir da relação dinâmica entre social e individual, sendo que as transformações sociais e individuais não são excludentes, antes influenciam diretamente na constituição da subjetividade.

Raposo (2006) ainda considera, diante da perspectiva proposta por González Rey, que

o sujeito subjetivado e com capacidade de subjetivação é o sujeito do pensamento, de linguagem e de emoção; o sujeito é intencional, participativo, criativo, generativo e reflexivo, (...) tem compromisso 
com práticas sociais, debate-se entre estratégias individuais e opções sociais e estabelece sua identidade pessoal e social (p. 16).

Para Wallon (in Galvão, 1995), sujeito é o todo que integra a afetividade, a motricidade, a inteligência e a dependência do outro, já que o homem é um ser social. Dessa maneira, o desenvolvimento do sujeito se dá em uma progressão na qual afeto e cognição se alternam e se diferenciam de sujeito para sujeito, visto que cada sujeito responde de maneira singular ao desenvolvimento dos estímulos sofridos e ao próprio estilo de vida.

O autor ainda destaca que para a formação da pessoa enquanto sujeito há existência do eu corporal e do eu psíquico. O eu corporal é o conhecimento do corpo físico pela interação com objetos concretos. Essa ação interativa permite ao sujeito ser capaz de reconhecer os limites do seu corpo, a experimentação de diferentes sensações, movimentos e o reconhecimento dos diferentes espaços. O eu psíquico necessita da construção do eu corporal e se inicia após a apropriação da consciência, por parte do sujeito, de si mesmo fisicamente.

Nas crianças, o eu psíquico designa mistura e confusões de personalidade. A criança, em um primeiro momento, tende a imitar as pessoas e a misturar a sua personalidade com a dos outros. É nessa fase, também, que a criança refere-se a si mesmo pelo nome e dialoga geralmente com um amigo imaginário.

Miglioli et al (1996) enfatiza que a construção do eu na teoria de Wallon depende essencialmente do outro, seja para ser referência, seja para ser negado já que a oposição que o outro faz frente ao eu, funciona como um instrumento de descoberta do eu de si próprio. A essa relação, Wallon deu o nome de eu-outro. Wallon (in Galvão, 1995) propõe, ainda, que o eu deve exteriorizar-se e, se necessário, colocar-se em confronto com o outro para expressar vivências subjetivas e de personalidade.

Diante da concepção de sujeito, em sua complexidade, que se constitui em uma relação dinâmica e recíproca entre social e individual, consideramos que o indivíduo com deficiência visual é um sujeito ativo e interativo, além de ser constituído pelo social e constituinte no social. Com base nas concepções das teorias apontadas, vemos que o outro está relacionado diretamente com o sujeito e que é na relação existente entre o sujeito e o outro que transformamos e somos transformados. Portanto, nos propusemos a fundamentar a importância da 
afetividade na constituição dos sujeitos e na sua relação com o outro, no desenvolvimento dos afetos, das emoções e da sua implicação na relação professoraluno. 


\section{CAPÍTULO 3 - A RELAÇÃO INDISSOLÚVEL ENTRE AFETIVIDADE E APRENDIZAGEM}

O termo afetividade remete a muitos como atenção, afeto, carinho, emoção e sentimentos. Contudo, afetividade é mais abrangente. Refere-se à busca de valores humanos, além de sugerir transformações, a começar de cada pessoa frente a si e aos seus atos.

A consideração da afetividade relacionada à aprendizagem aplicada à educação sugere a busca por inovações e produção de sentido social. Isto implica que afetividade propõe novos parâmetros educacionais nos quais educandos, educadores e toda a comunidade escolar considerem a forma completa do sujeito.

Segundo Rossini (2001), a afetividade é importante porque ela é a base da vida. Dessa maneira, se o ser humano não está bem afetivamente, sua ação, como ser social, estará comprometida, sem expressão e vitalidade.

Na perspectiva de Wallon (in Galvão, 1995), quando aborda a afetividade, as emoções, que como os sentimentos são manifestações da afetividade, têm papel importante no desenvolvimento do sujeito, sendo-lhe atribuída à função de manifestar suas vontades e desejos. Em geral são exteriorizadas de maneira a expressarem um universo importante e perceptível, mas pouco estimulado pelos modelos tradicionais de ensino. Além disso, as emoções dependem fundamentalmente da organização dos espaços para se manifestarem. Conforme as idéias de Wallon (apud Miglioli et al, 1996) a escola insiste em imobilizar a criança em uma carteira, limitando a fluidez das emoções e do pensamento, tão necessários para o desenvolvimento completo do sujeito.

Para Vigotski (1989), o ser humano constitui-se enquanto tal na sua relação com o outro, de maneira que ele se transforma de apenas biológico para social e histórico, em um processo no qual a cultura é essencial para outra configuração individual e social, já que o autor traz a concepção dialética de homem e cultura.

Vigotski, citado em Tassoni (2000), ao destacar a importância das interações sociais, apresenta a idéia de mediação e da internalização como aspectos fundamentais para a aprendizagem, defendendo que a construção do conhecimento ocorre a partir de um intenso processo de interação e afetividade entre as pessoas. 
Portanto, é a partir de sua inserção na cultura que a criança, por meio da interação social com as pessoas que o rodeiam, vai se desenvolvendo. Apropriando-se das práticas culturalmente estabelecidas, ela evolui das formas elementares para funções superiores de pensamento que a ajudarão a conhecer a si própria e o universo ao seu redor. Nesse sentido, destacamos a importância do outro não somente no processo de construção do conhecimento, contudo também no processo de constituição do próprio sujeito e de suas formas de agir já que ambos, sujeito e sociedade, se transformam contínua e mutuamente.

Para Tassoni (2000), a relação que caracteriza o ensinar e o aprender transcorre a partir de vínculos entre as pessoas e inicia-se no âmbito familiar. A base desta relação vincular é afetiva, pois é por meio de uma forma de comunicação emocional que o bebê mobiliza o adulto, garantindo assim os cuidados que necessita. Portanto, é o vínculo estabelecido entre o adulto e a criança que sustenta a etapa inicial do processo de aprendizagem.

Da mesma forma, é a partir da relação com o outro, pelo do vínculo afetivo que, nos anos iniciais da sua vida, a criança vai tendo acesso ao mundo simbólico e, assim, conquistando avanços significativos no âmbito cognitivo. Vigotski (1996) destaca essa compreensão quando afirma que

De acordo com esse ponto de vista podemos definir o bebê como um ser maximamente social. Toda relação da criança com o mundo exterior, inclusive a mais simples, é a relação refratada através da relação com outra pessoa (p. 285). ${ }^{3}$

Nesse sentido, para a criança, torna-se importante o papel do vínculo afetivo, que inicialmente apresenta-se na relação pai-mãe-filho e, muitas vezes, irmãos. No decorrer do desenvolvimento, os vínculos afetivos vão ampliando-se e a figura do professor surge com grande importância na relação de ensino e aprendizagem. A partir do momento em que o professor entra em contato com o aluno já se cria uma relação e várias conseqüências podem ocorrer, causando diferentes interações na sala de aula por meio do vínculo criado. Por isso, concordamos com Tacca (2004) que afirma

\footnotetext{
${ }^{3}$ Os trechos citados de textos em língua estrangeira são traduções livres.
} 
o professor, sem dúvida, (...) está em posição de confirmar o aluno como sujeito, devolvendo-lhe seu valor como pessoa e como aprendiz. É o "outro social" essencial para o desenvolvimento intelectual, afetivo, social e de todas as outras dimensões e aspectos que integram o aluno como ser humano (p.101).

É fundamental a consciência, por parte do professor, da diversidade que se tem em sua sala de aula. Tal diversidade sugere subjetividade individual - conceito que será abordado no próximo capítulo - que deve ser respeitada tanto pelo professor como pelo aluno. Destacamos, ainda que a relação entre os sujeitos deva priorizar o diálogo, visto que estamos em uma concepção de educação dialética, dialógica e recíproca. É por meio do diálogo que os sujeitos se interagem e se ajudam mutuamente, ressaltando que "nem o aluno, nem o professor são os mesmos depois do diálogo" (Tunes, Tacca e Bartholo Júnior, 2005, p. 695) já que o diálogo é o canal que abre possibilidade de influência sobre si e principalmente sobre o outro.

Toda aprendizagem está implicada pela afetividade, pois ocorre a partir das interações sociais, em um processo vincular. Ao pensarmos, especificamente, na aprendizagem escolar, a trama que se tece entre professores, alunos, conteúdos escolares, leitura e escrita não acontecem puramente no campo cognitivo. Existe uma base afetiva permeando essas relações.

Vigotski (2001) ainda destaca que a aprendizagem é a fonte do desenvolvimento e que essa se inicia antes do ingresso na escola e continua além dela. A criança chega à escola com algumas aprendizagens e, de certa forma, desenvolveu-se para ter chegado ali.

O professor não pode esquecer que, antes da sua intervenção, a criança já traz de casa algumas relações de ensino-aprendizagem, mesmo sendo a relação pai-filho diferente da relação professor-aluno.

Dessa maneira, concluímos que a afetividade não é uma parte da psicologia humana dissociada do sujeito. Ao contrário, o sujeito, a partir das interações sociais, em um processo vincular, se desenvolve progressivamente, como propõe Vigotski, com a unidade afeto-intelecto, contrapondo-se à Wallon que defende a alternância entre afeto e cognição. 
González Rey apoiado na teoria de Vigotski sobre a unificação afeto-intelecto, contribui para a compreensão dos amplos e complexos processos da psique humana apresentando a concepção de subjetividade nas dimensões social e individual que será apresentada no próximo capítulo. 


\section{CAPÍTULO 4 - AS CONTRIBUIÇÕES DE GONZÁLEZ REY PARA A COMPREENSÃO DA SUBJETIVIDADE}

Na teoria da subjetividade de González Rey (2003), a categoria subjetividade constitui uma tentativa, na perspectiva histórico-cultural, de compreender os processos da psique humana diante da sua complexidade e da sua amplitude. Os processos psicológicos são compreendidos como sistema complexo nos quais sujeito e sociedade estabelecem uma relação indissociável em um sistema aberto e de contínuo desenvolvimento sendo que sujeito e sociedade se organizam de formas diferentes e em espaços diferentes.

González Rey (1999, p.108) define a subjetividade como

a organização dos processos de sentido e de significação que aparecem e se organizam de diferentes formas e em diferentes níveis no sujeito e na personalidade assim como nos diferentes espaços sociais em que o sujeito atua.

Diante da compreensão do sujeito e da sociedade, o autor destaca duas dimensões da subjetividade que atuam interdependentemente: a individual e a social. Cabe ressaltar que os processos ocorridos no plano individual não excluem os processos ocorridos no plano social. Isso se dá porque individual e social estabelecem uma relação recíproca nos processos subjetivos, ou seja, a subjetividade é social e individual simultaneamente (Mitjáns Martínez, 2005).

A subjetividade individual constitui-se historicamente nos espaços sociais, isto é, nenhuma atividade do sujeito por si só será isolada da conjuntura de sentido e significados que caracterizam a sociedade. Esse fato aponta para a "multidimensionalidade e complexidade da constituição psicológica" (Mitjáns Martínez, 2006).

Segundo González Rey (2003), é na subjetividade individual que a história de cada indivíduo, dentro da cultura em que está inserido, se constitui em suas relações sociais. O sujeito é, portanto, o momento vivo da história da sua subjetividade.

A subjetividade social, definida por Gonzaléz Rey (idem), surge para desmistificar a subjetividade como um fenômeno meramente individual. Dessa 
maneira, o autor a apresenta como um sistema complexo que ocorre simultaneamente no individual e no social, assumindo os processos sociais como processos dentro da complexidade do sistema e não mais como ações externas aos indivíduos. O indivíduo, diante disso, é constituinte dos processos sociais e também é constituído socialmente.

González Rey (ibidem) ainda enfatiza que

A subjetividade social não é uma abstração, é o resultado de processos de significação e sentido que caracterizam todos os cenários de constituição da vida do sujeito, e que delimitam e sustentam os espaços sociais em que vivem os indivíduos, por meio da própria perpetuação dos significados e sentidos que os caracterizam dentro do sistema de relações em que eles atuam e se desenvolvem (p. 205-206).

Além disso, notamos que, na concepção de subjetividade social, a constituição do indivíduo não é um processo que segue uma única forma, já então, definida e universal. Contrapondo-se a isso, a constituição social desse indivíduo se dá em um processo diferenciado, na qual as ações ocorridas terão conseqüências para o desenvolvimento individual, bem como para o desenvolvimento social. Logicamente, a ação do indivíduo no contexto social não apresentará, imediatamente, uma marca. Contudo, essa mesma ação será correspondida por inúmeras outras ações dos demais indivíduos que compõem tal contexto. Consideramos, portanto, que a subjetividade social, assim como a individual, não se delimita a um espaço e um sujeito. Ao contrário, ela gera novas formas de funcionamento das dimensões social e individual que se relacionam contínua e processualmente na produção de sentidos e significados.

Diante da concepção de subjetividade que assumimos, o sentido subjetivo surge como parte integrante e essencial na organização subjetiva. A definição dada por González Rey (2004) aponta que sentido subjetivo é

um tipo de unidade auto-organizada de subjetividade que se caracteriza por uma integração de significados e processos simbólicos em geral e de emoções, nas quais um elemento não está determinado pelos outros, embora tenha capacidade de evocar os outros (p. 17) 
O sentido subjetivo implica os processos simbólicos e as emoções, sendo considerado que em um mesmo sistema, os processos simbólicos evocam as emoções e as emoções evocam os processos simbólicos, sem que sejam absorvidos um pelo outro. A categoria de sentido subjetivo implica a produção de sentido e, necessariamente, as dimensões social e individual como elementos fundamentais na constituição do sentido. Ressaltando que o sentido sempre está presente nos processos de significação. $O$ fato de estar presente não significa que 0 sentido será definido pelo processo de significação, sendo o sentido determinado pela nossa consciência que é procedente do psicológico (González Rey, 2003).

González Rey (2004, p.10) traz a questão do significado do outro quando afirma que

\footnotetext{
o outro é significativo no desenvolvimento da pessoa somente quando se converte em um sentido subjetivo que está sempre relacionado à emocionalidade.
}

Por essa razão, o outro tem um papel essencial para a formação do sujeito em seu desenvolvimento moral, sua personalidade, enfim, do próprio desenvolvimento humano (idem).

Apresentamos, a seguir, relatos que apontam elementos constitutivos dos sentidos subjetivos sobre a deficiência visual de duas professoras, assim como da relação afetiva e sua influência na aprendizagem dos alunos, com os quais tive a oportunidade de desenvolver estágio em uma disciplina do curso de Pedagogia. 
PARTE II

SEGUNDA FASE

EXPERIÊNCIAS VIVENCIADAS 


\section{CAPÍTULO 1 - RELATOS DE EXPERIÊNCIA}

A educação no Brasil, até pouco tempo, ficou presa dentro dos portões da escola. Essa educação é, somente, o cumprimento das exigências curriculares do Ministério da Educação, isto é, apenas um repasse de conteúdos programáticos. Isso não é educação. Isso é formatação, visto que os educandos passam a ser padronizados, ou seja, mesmos peso, volume, tamanho e forma. O resultado mais relevante desse processo é a desconsideração da necessidade educacional especial, transitória ou permanente, dentre tantos outros aspectos.

A educação, de acordo com o que acreditamos, deve despertar no sujeito a consciência de sua capacidade de transformar-se em um sujeito autônomo e pensante, por meio de um processo de construção de uma educação instituinte. Essa educação deve ser capaz de provocar mudanças no sujeito, com o objetivo de formar uma sociedade melhor, mais igualitária e humana, com o propósito liberdade, eqüidade, justiça para todos.

Estimando uma mudança, não somente teórica, mas de fato e de verdade, é preciso quebrar alguns paradigmas, primeiramente, em cada um de nós. Não se deve esperar investimentos financeiros e/ou governamentais para começarmos a mudar. Não se deve esperar a eficácia de uma prática de ensino ou de um projeto pedagógico adotado em outro país, ou até mesmo em outro estado brasileiro, para começarmos a mudar. É necessário acreditar que é possível mudar a começar de nós.

Os profissionais da área nem sempre estão preparados para atuar como educadores. Está mais que na hora de deixar de existir a figura do educaDOR, com referência à palmatória, à régua, ao milho, ao chicote, ao grito e às ameaças; para dar lugar ao educador entusiasmado com o que faz, apaixonado pela arte de ensinar e aprender. Esse educador, como nos ensina Freire (1996), deve buscar a autonomia de seus alunos, a ética do ser humano e acreditar na capacidade do aluno, afinal esse é um sujeito ativo e interativo no processo e o educador deve enxergá-lo como tal. 
Com o objetivo de discutir as experiências vivenciadas, foram relatados alguns fatos que contribuíram para a realização deste trabalho e das conclusões a cerca das nossas discussões.

Em 2006, durante os dois semestres, cursei a disciplina Projeto 4, fases A e B. Cada fase em um semestre letivo, no projeto de (Re)Educação Matemática, sendo trabalhada a questão da mediação e da necessidade do outro para a formação do Conhecimento e, neste caso especificamente, do Conhecimento Matemático.

O Projeto 4, antes chamado de estágio, é o momento privilegiado em que o profissional da educação se vê inserido em um contexto formal de práticas educativas e não mais somente teórico. O Projeto 4 é dividido em duas fases, tendo cada fase cento e vinte horas obrigatórias para a sua conclusão. Dessa forma, são necessárias duzentas e quarenta horas.

O orientador desse projeto dividiu o trabalho realizado da seguinte forma: cento e oitenta horas (noventa em cada fase do projeto) em uma Escola Classe, indicada por ele, que se localiza na Asa Norte, Brasília - Distrito Federal e sessenta horas (trinta em cada fase) para planejamento das atividades.

Cabe ressaltar, que na extensão da educação para a vida, utilizamos, durante as atividades do Projeto 4, aspectos corriqueiros e reais da vida das crianças para que fosse efetivada a aplicação dos ensinamentos no dia-a-dia.

Da mesma forma, procurei, enquanto estagiária - e aqui é importante ressaltar isso - incentivar cada criança, independente de apresentar deficiência, para uma construção de conhecimento autônomo, sempre explorando, de diversas maneiras, as várias possibilidades existentes na resolução de uma conta ou expressão matemática, por exemplo.

Em razão de postura ética, constituinte também no Projeto 4, os nomes adotados, tanto para os alunos quanto para as professoras, são fictícios.

Foram realizadas atividades nas salas de aula das professoras Cláudia e Marcela. As duas são professoras do Segundo Ano do Ensino Fundamental (antiga Primeira Série) e a escola, institucionalizada e intitulada inclusiva, têm alunos com necessidades especiais em sala.

Delimitamos nossos relatos às ações, atitudes e atividades das duas professoras para com os alunos com deficiência visual, aqui chamados de Eduardo (aluno da professora Cláudia) e Artur (aluno da professora Marcela). 


\section{1- Relato sobre Cláudia e Eduardo}

Cláudia é uma jovem senhora, casada, trabalha há vinte e três anos em sala de aula e está aberta às novas tendências educacionais, além de participar de cursos de formação continuada para aprimorar sua prática pedagógica. Pareceu-me dinâmica, paciente, tranqüila, calma, aberta aos relacionamentos com todos os alunos, sem exceção, trabalha seriamente e acompanha os alunos processualmente. Têm dois alunos com dificuldade de aprendizagem e Eduardo, o aluno com deficiência visual.

Eduardo tem oito anos, usa óculos e ainda assim tem a visão comprometida. É considerado deficiente visual, especificamente com baixa visão, uma vez que tem a acuidade visual reduzida e precisa de contraste de cor para melhor visualização. Muitas vezes se mostra impaciente por não conseguir enxergar as letras, desenhos ou qualquer objeto mostrado em sala e costuma se posicionar sempre à frente dos demais alunos para tentar ver. Alguns alunos se sentem incomodados e logo reclamam para a professora que Eduardo está atrapalhando a visualização e o entendimento deles, já que Eduardo fica muito próximo à professora.

Cabe ressaltar que durante toda a participação na sala da professora Cláudia, as informações sobre todos os alunos foram compartilhadas. Cláudia soube, por meio do professor Cristiano, orientador do Projeto 4, da minha experiência em adaptação de material e acessibilidade para pessoas com deficiência visual adquirida no LDV - Laboratório de Apoio ao Deficiente Visual. Esse fato nos deu a oportunidade de conversar abertamente e levantar questionamentos sobre as formas mais adequadas de desenvolver o trabalho, sobretudo para Eduardo.

Confeccionamos, juntas, cadernos especialmente para Eduardo, com letras de tamanho maior, usando contraste entre a cor do papel e a cor da fonte, além de texturas e materiais diferenciados para adaptação de diversos livros, matérias e aulas. Buscamos explorar os materiais que Eduardo mais se identificava como materiais concretos e acessíveis a sua realidade, a exemplo de sucata, areia, argila e tecidos.

Eduardo não é usuário do Sistema Braille, sistema de leitura e escrita para pessoas cegas, inventado pelo francês Louis Braille. Pelo fato de Eduardo gostar muito de desenhar, Cláudia e eu preparamos atividades que relacionavam desenho 
e escrita, usando alfabeto feito em madeira e em EVA, além das caixas de areia, lixa e argila para trabalhar o desenvolvimento da sensibilidade tátil.

Nas aulas de informática, Eduardo era acompanhado por Cláudia. Ela, apesar de não saber manusear bem o computador, procurava auxiliá-lo nas atividades propostas pela professora de informática. Observei que o fato de acompanhar os alunos com necessidades educacionais especiais às aulas de informática não era rotineiro das outras professoras.

Cláudia trabalhava fortemente a questão da inclusão nas atividades. A leitura de histórias infantis sempre apresentavam uma lição que ser diferente é normal e que somos todos diferentes, mas devemos tratar os demais com eqüidade. Além disso, a professora trabalhou nossos direitos e também deveres como cidadãos. Nessas atividades com livros infantis, Cláudia me deu oportunidade de realizar atividades com as crianças que trabalhava com o conhecimento do corpo, conhecimento do outro e conhecimento do grupo como um todo.

Assistimos a uma peça, baseada no livro de Rubem Alves chamado $A$ porquinha do rabo esticadinho, em que dois integrantes da companhia teatral tinham Síndrome de Down. No retorno do teatro, ao chegarmos à escola, a professora reforçou sobre o princípio da inclusão e propôs aos alunos momento de interação e reflexão sobre as diferenças das pessoas. Durante essa atividade, observamos que as crianças estavam interagindo mais umas com as outras e que como conseqüência da peça, que tratou sobre diferença, os alunos estavam mais respeitosos, solidários e abertos a novas experiências. Foi nesse momento que propus a Cláudia que fizéssemos uma vivência com as crianças. Essa vivência foi ministrada em uma manhã e abrangeu deficiências física, visual e auditiva. As crianças ficaram empolgadíssimas com a vivência e aceitaram bem os desafios frente às diferenças, além disso, se propuseram a ajudar a si próprios, os outros, a professora, a mim, a comunidade escolar e levar ao conhecimento dos pais o trabalhávamos em sala. Com atividades como essas, conseguimos criar um clima harmonioso, pacífico e de respeito em nossa sala de aula.

Cláudia vê Eduardo como um sujeito com possibilidades e procura sempre viabilizar o entendimento dele nas atividades que são propostas. Ela não esqueceu dos demais alunos em sua sala e também auxiliou os alunos com dificuldades de aprendizagem. 
As aulas na Escola Parque ${ }^{4}$ eram às quintas-feiras. É interessante ressaltar que no dia seguinte das atividades da Escola Parque as crianças chegavam à escola muito inquietas e demonstravam dificuldades de concentração. Às sextasfeiras, Cláudia sempre contava uma história para que eles chegassem, se acalmassem e acostumassem com a rotina daquele dia, especialmente. A espera ansiosa pelo final de semana também é considerado um fator que contribuía para a agitação dos alunos.

Cláudia promoveu várias atividades lúdicas relacionadas à realidade dos alunos que proporcionaram uma facilitação na aprendizagem de todos, inclusive com adaptação de acesso para Eduardo. Cláudia evitava protegê-lo das situações e conflitos do dia-a-dia, porque acreditava que Eduardo precisava vivenciar certas circunstâncias para sua própria aprendizagem e amadurecimento, além de conseguir superar com independência suas necessidades, sem necessariamente depender sempre de alguém.

A família de Eduardo mostrou-se, por vezes, indiferente à deficiência dele. Cláudia tentou, com freqüência, conversar com a família sobre as possibilidades de melhor aproveitamento do conteúdo e o apoio adequado em casa, no entanto, não obteve resultados satisfatórios. Esse fator não interferiu trabalho de Cláudia tampouco as atividades em sala. Cláudia soube trabalhar positivamente, não reforçando a deficiência de Eduardo como algo negativo e impossibilitante. Ao contrário, procurou incentivar Eduardo a perseverar e a alcançar um resultado sempre melhor do que ele já tinha apresentado, mesmo ele tendo dificuldades para enxergar. A deficiência e as condições cotidianas devem ser entendidas como um fator a ser trabalhado e adequado e não como um fator que impede a aprendizagem.

O projeto visava a (Re)Educação Matemática com a construção do conhecimento matemático de uma forma lúdica, diferentemente do convencional. $O$ apoio de materiais e a adaptação contribuíram para a aprendizagem dos conhecimentos matemáticos de Eduardo. Essa aprendizagem deu-se, particularmente, nas noções de quantificação, separação e comparação; além das operações simples de adição e subtração.

A maneira como Cláudia abriu sua sala de aula para mim foi uma experiência enriquecedora. A grande interação gerada entre nós nos deu a oportunidade de

\footnotetext{
${ }^{4}$ De acordo com Santiago Nuad (2007), a Escola Parque é destinada à prática de esporte, aulas de artes e música. Disponível na página http://www.secom.unb.br/unbagencia/ag1007-46.htm.
} 
trocar idéias, questionamentos, compartilhar sugestões e opiniões, trabalharmos juntas na construção de material de acesso para Eduardo, planejarmos atividades, mediarmos a construção do conhecimento coletivo e também individual e dialogarmos sobre a prática pedagógica e como fazer para aperfeiçoá-la.

\section{2 - Relato sobre Marcela e Artur}

Marcela é casada, está há pouco tempo em Brasília e trabalha há doze anos em sala de aula. Mostrou-se impaciente, em alguns momentos gritou com seus alunos e pareceu-me, chegar à escola, irritada, desanimada e cansada.

Marcela tem um aluno com cegueira, um com deficiência física que utiliza um andador para auxílio na locomoção e um outro aluno que estava sendo submetido a exames médicos e acompanhamento psicológico pela Secretaria de Estado de Educação do Distrito Federal. Até o final do meu estágio, ainda não se sabiam, exatamente, o diagnóstico desse aluno, o que não deveria interferir em nada no trabalho a ser desenvolvido, afinal a professora deveria saber como melhor trabalhar com ele, mas infelizmente estava presa à espera do diagnóstico médico.

O aluno com deficiência física apresentava bom desempenho nas atividades em sala, sempre com muita independência e autonomia. Este fato chamou minha atenção, pois a professora não proporcionava apoios mais específicos e parecia considerar o aluno capaz de desenvolver-se sem apoios internos e especializados.

Assim como Eduardo, Artur também tem idade avançada em dois anos em relação aos demais alunos da turma, desconsiderando os que porventura reprovaram, abandonaram ou evadiram.

Artur usa óculos, mas nem sempre os leva para a escola, e não é usuário do sistema Braille. É considerado cego por ter a acuidade visual menor que 0,05 no melhor olho, mesmo com a correção ótica, segundo informações da professora de sala de aula. Cabe aqui ressaltar que essas foram as únicas informações que a professora nos deu. Marcela não sabia sobre deficiência visual, não quis tomar conhecimento sobre as melhores formas de adaptação e acesso para Artur, nem tampouco se importou com a nossa presença em sala, além de não nos dar abertura para interagir com as crianças. 
Artur não tem materiais adaptados e em determinadas situações mostrou-se inquieto pela falta de acesso às informações disponibilizadas e, por isso, se recusava, por vezes, a realizar as atividades.

Muitas vezes, ele chegou à escola sem os óculos e em condições inadequadas, sem cuidados de higiene pessoal e saúde. Esse fato foi razão de rejeição por parte dos colegas e da própria professora que não o orientava tampouco buscava uma alternativa para ajudá-lo.

Pareceu-me que o fato de estar ali, presente fisicamente na escola, não fazia mais sentido para Artur, já que por falta de opção se via obrigado, pela família, a freqüentar a escola.

Em situações adversas, a deficiência de Artur era vista como um impedimento à realização de tarefas e atividades, o que o fez, muitas vezes, desistir antes mesmo de tentar solucionar uma expressão matemática de operações simples, por exemplo.

Como Marcela não adaptava materiais para Artur, nem buscava ajudá-lo nas atividades, eu, juntamente com outra colega do curso, sentimos a necessidade de criar condições de acesso às informações, de adaptar material e de alfabetizar Artur, mesmo após insistência de Marcela dizendo que não seria satisfatório e que nossa atitude solidária não daria certo. Artur também insistia dizendo que não valeria tentar porque já não conseguiria.

Alguns colegas de classe tentavam ajudá-lo em determinados momentos, mas nem sempre era possível, visto que a professora dificultava a interação entre os colegas, pois dava continuidade ao assunto abordado sem uma nova organização. Os momentos de ajuda dos colegas coincidiram com os momentos em que a professora não estava em sala ou quando ela não reforçava a deficiência de Artur. Nas aulas de informática, a turma era dividida em dois grupos por causa da quantidade de computadores disponíveis na sala de informática. Cada grupo ficava 50 minutos com a professora de informática. Artur era o único aluno a ficar nos dois grupos a pedido da própria Marcela.

Observei que quando Artur não conseguia realizar uma atividade, e esse fato acontecia várias vezes no turno de aula, a inquietação e a insatisfação eram claramente percebidas. Artur se deslocava de forma atordoada e desequilibrada, batendo nos armários, cadeiras e mesas, deixando Marcela nervosa e impaciente. Nesses momentos ela gritava: "Dá para você deixar seus colegas aprenderem?". Eu me questionava: "E ele não tem o direito de aprender?". 
Marcela mostrou-se, diversas vezes, indiferente quando tentávamos conversar com ela sobre algumas posturas adotadas que não eram satisfatórias e agradáveis sobre o tratamento dela, especialmente com Artur.

A cegueira de Artur pareceu-me ser reforçada negativamente em vários momentos e em diversas situações. Ao invés de tentar trabalhar de diferentes formas com ele, impunha a questão de ser igual para todos, achando que isso bastava para a inclusão.

A professora pareceu-me não se importar com a necessidade de adaptações de acesso das informações e de materiais para Artur. Esse fato ficou claro, principalmente, nas aulas de matemática ${ }^{5}$. O trabalho com atividades lúdicas boliche com garrafa pet e com quantificações de acordo com a cor da tampa ou do rótulo feito pela professora, o jogo de agrupar e desagrupar para o ensino de unidade, dezena e centena e o bingo das operações simples - prejudicava a participação de Artur porque as atividades propostas pela professora precisavam necessariamente da visão. Propusemos adaptações para todas essas atividades, contudo Marcela não acatou com nossas sugestões, deixando Artur sempre excluído.

\footnotetext{
${ }^{5}$ As aulas de matemática eram mais significativas por causa do projeto que fazíamos na escola que era exatamente a $(\mathrm{Re})$ Educação Matemática que, além das atividades lúdicas, tinha também como objetivo a construção coletiva do conhecimento.
} 


\section{CAPÍTULO 2 - ANÁLISES DOS RELATOS DE EXPERIÊNCIA}

A partir da discussão realizada pela fundamentação teórica e pelas experiências relatadas, verificamos que o processo de inclusão escolar depende essencialmente dos sujeitos que estão inseridos no contexto dos quais participam.

As experiências vivenciadas e relatadas nesse trabalho nos possibilitaram a compreensão da importância da unificação afeto-intelecto para a aprendizagem. Para tanto, buscamos identificar características, atitudes e posturas de duas professoras, Cláudia e Marcela, para com seus alunos com deficiência visual, respectivamente, Eduardo e Artur, e, a partir daí, apontar elementos que articularamse na constituição do sentido subjetivo sobre a deficiência visual compreendido em cada um dos casos.

Conforme as Diretrizes Nacionais para a Educação Especial na Educação Básica, Artigo $2^{\circ}$,

os sistemas de ensino devem matricular todos os alunos, cabendo às escolas organizarem-se para o atendimento aos educando com necessidades educativas especiais, assegurando as condições necessárias para uma educação de qualidade para todos (Brasil, MEC, 2001).

A educação inclusiva implica em uma educação "que reconheça as diferenças e, respeitando-as, possa conviver com elas" (Ferreira e Guimarães, 2003, p. 154). que gera um processo contínuo de melhoria da escola, com o fim de utilizar todos os recursos disponíveis, especialmente os recursos humanos, para promover a participação e a aprendizagem de todos os alunos.

$\mathrm{Na}$ escola em que o projeto foi efetivado, havia o cumprimento do Artigo $2^{\circ}$ das Diretrizes Nacionais para a Educação Especial na Educação Básica no quesito de matricular todos os alunos. Contudo a inclusão mesmo sendo institucionalizada e instituída pela escola não foi entendida por nós como real.

Inclusão escolar não é apenas matricular um aluno com necessidades educacionais especiais em uma classe regular de ensino. É assegurar a permanência do aluno na escola, mesmo que para isso sejam necessárias 
mudanças pedagógicas, curriculares, físicas e até, profissionais para que o direito do aluno e o dever do Estado sejam cumpridos.

A sala de apoio, durante o período em que estive na escola, pareceu-me funcionar como um depósito de material, com pequena participação e freqüência de alunos e com a atuação esporádica de professores, apenas, na presença de psicólogos da Secretaria de Estado de Educação do Distrito Federal. A sala de apoio deveria funcionar ativamente como uma modalidade de atendimento pedagógico com a finalidade favorecer a aprendizagem de educandos com necessidades educacionais especiais na qual um professor especializado se torna o mediador do processo de aprendizagem, trabalhando individualmente ou em grupo, de acordo com a necessidade de cada educando. Cabe ressaltar que a sala de apoio não deveria funcionar como uma sala de reforço escolar, no sentido de repetir aquilo que a professora leciona em sala de aula, contudo deveria funcionar como um espaço de construção do conhecimento, com a mediação, a adaptação de materiais e incentivo à aprendizagem do educando ${ }^{6}$.

Feltrin (2004) afirma que "a sociedade e a escola, mais os professores na sala de aula, devem estar preparados e capacitados para poder tratar e conviver com a diferença" (p.15). Assim, equivale dizer que a instituição deve estar provida de recursos humanos e materiais que permitam ao aluno com necessidades educacionais especiais ser "acolhido, valorizado, incluído e não simplesmente tolerado, no seu grupo" (idem, p. 16).

A inclusão de Eduardo na turma em que Cláudia lecionava e a criação do ambiente que promoveu a aprendizagem colaborativa e mediada pelos alunos deram-se por mérito da professora, cujas atitudes e posturas foram afirmativas em relação à deficiência visual de Eduardo.

Concordamos com Muniz (2002) quando afirma que "a aprendizagem não é um ato solitário, mas eminentemente solidário" (p. 71), de forma que o professor e os demais alunos possuem um papel fundamental nesse processo. No caso de Eduardo, a aprendizagem foi facilitada por aspectos e elementos que nos levam a compreender o sentido subjetivo afirmativo de Cláudia sobre a deficiência visual. Além de disponibilizar materiais com adaptação de acesso para Eduardo, Cláudia preocupou-se com a constituição de Eduardo como sujeito ativo e interativo no

\footnotetext{
${ }^{6}$ Informações sobre o trabalho realizado na sala de apoio: retiradas do site http://www.geocities.com/HotSprings/Oasis/2826/avaliacao.html
} 
processo de desenvolvimento escolar e cidadão, como também em seu processo de desenvolvimento humano.

A organização de um ambiente facilitador da aprendizagem e a inserção dos amigos de Eduardo na mediação da construção do conhecimento foram fatores que estimularam Eduardo a buscar e conhecer algo novo e inovador para ele e seus amigos.

A relação afetiva e vincular estabelecida entre Cláudia e Eduardo promoveu a construção do conhecimento de forma coletiva e dinâmica na qual o diálogo fez-se presente, o que gerou possibilidade de influência tanto de Cláudia sobre Eduardo quanto de Eduardo sobre Cláudia, afinal o diálogo é o canal que proporciona abertura para interação e ajuda mútua.

As atividades lúdicas, como os jogos educativos em matemática, propostos por Cláudia, estimularam Eduardo a aprender e desenvolver novos conhecimentos e proporcionaram um momento de práxis, isto é, a união dialética da teoria e da prática, além da possibilidade de interação de Eduardo com os demais colegas de classe e com Cláudia. Esse momento de interação estimulou Eduardo a investigar a maneira com que os demais participantes dos jogos pensaram e agiram no decorrer das atividades.

Esse fato foi possível porque Cláudia enxergava Eduardo como um sujeito e não apenas como um deficiente. Cláudia, partindo dos quatro pilares da Educação aprender a ser, aprender a conviver, aprender a fazer e aprender a conhecer (Jacques Delors para a UNESCO, 1999) -, acreditava nas possibilidades de Eduardo, ou seja, que ele é capaz de aprender e se desenvolver como os demais alunos de sua sala de aula. Ela o enxergava como sujeito ativo e interativo no seu processo de aprendizagem, capaz de desenvolver-se e de adquirir conhecimentos para sua formação educacional e, principalmente, para constituir-se individual e socialmente de diferentes formas e em diferentes espaços.

Ao considerar a importância da integração da subjetividade frente ao sujeito que aprende, González Rey (2006) afirma que "o sujeito aprende como sistema e não só como intelecto" (p. 33). Entendemos, dessa maneira, que as emoções e a motivação do sujeito são fundamentais no processo de aprendizagem, visto que emoções e motivação são resultados não apenas de situações vivenciadas, mas em sentidos subjetivos constituídos em diferentes espaços e em diferentes momentos, produzindo distintas significações para o sujeito. 
Tendo como referência os estudos de González Rey (apud Tacca, 2005), o sentido subjetivo, que surge no âmbito de uma experiência é um resultado, a partir de uma reorganização, releitura e nova interpretação do próprio sujeito que se relaciona diretamente com o social e com o individual, ou seja, o sentido subjetivo não é a concretização imediata do sujeito sobre a experiência. Assim, as dimensões individual e social, como elementos fundamentais na constituição de sentido subjetivo, estão necessariamente implicadas na produção de sentido de cada sujeito.

Dessa maneira, podemos compreender que Cláudia, a partir da sua reorganização, releitura e reelaboração da deficiência, da capacidade do sujeito com deficiência e da inclusão escolar, constituiu um sentido subjetivo afirmativo sobre a deficiência visual. Eduardo, como sujeito ativo desse processo, também constituiu um sentido subjetivo para a sua aprendizagem e para a relação dialógica com Cláudia e seus pares, o que contribuiu, de forma significativa, para a constituição da subjetividade de todos.

Marcela pareceu-nos reforçar a deficiência de Artur como algo que o impossibilitava de ser, conviver, fazer e conhecer. Para Marcela, Artur mostrava-se como um indivíduo inconveniente, incapaz de aprender e impossibilitado para convivência social em razão de sua deficiência visual. Pudemos perceber que as atitudes, ações e posturas de Marcela articularam elementos significativos que nos levam à compreensão do sentido subjetivo constituído por essa professora em relação à deficiência visual de Artur. Nesse sentido, é importante destacar que não foi esta a nossa compreensão sobre o aluno com deficiência física, que não demandava apoios ou adequações específicos por parte da professora. A única adaptação observada foi em sua carteira escolar que apresentava um apoio lateral para guardar o material utilizado em sala.

Por fim, notamos que a aprendizagem de cada aluno foi diferente e que o outro, nessa relação, caracterizou-se pelo sistema de sentidos subjetivos envolvidos. Isso significa que a construção social da deficiência visual e a produção de sentido subjetivo sobre a deficiência visual de Cláudia e Marcela foram relevantes para a determinação da ação delas frente a Eduardo e a Artur, respectivamente. 
PARTE II

TERCEIRA FASE

CONSIDERAÇÕES FINAIS 


\section{CONSIDERAÇÕES FINAIS}

O presente trabalho fez toda a diferença para as minhas idéias relacionadas à prática educativa, ao sentido subjetivo e ao cotidiano escolar. Quando penso em sala de aula não tenho mais a concepção ideal que muitas teorias estudadas no decorrer da minha graduação demonstraram, mas sim um espaço em que as crianças são diferentes e constroem suas significações e sentidos há seu tempo e modo, apesar da (ainda) pressão de um sistema que insiste em nivelar o seu desenvolvimento e a sua aprendizagem.

Vejo que as minúcias da prática são muito influenciadas pelos objetivos profissionais e pessoais daqueles que regem uma turma e que seus conceitos e preconceitos estão presentes, nitidamente, em todas as suas atitudes, características, ações e posturas.

O nosso desenvolvimento, enquanto sujeitos, se dá em caráter progressivo em que afeto e intelecto são unificados. Além disso, somos caracterizados pela nossa personalidade e esse fato nos torna diferente dos demais, ou seja, nossa personalidade nos torna sujeitos singulares.

Assim, as pessoas se dão a conhecer por sua personalidade, ou seja, por seus sentimentos, pensamentos e comportamentos e devem ter sempre a consciência de que suas características personológicas influenciam todo um processo de construção da subjetividade social e como é o caso do professor, a construção subjetiva dos sujeitos, que são seus alunos.

Quando a prática não é acompanhada por uma reflexão pontual acerca disso, existe a possibilidade de dar vazão à práticas errôneas e à impressão de uma marca significativa, profunda e negativa, em relação ao que vem a ser o processo de construção do conhecimento do sujeito inserido no contexto social. E isso será levado por toda a trajetória do sujeito, mesmo quando ele conseguir (re)elaborar as situações pelas quais passou.

A partir da interação do sujeito com os outros sujeitos e com o contexto social, as relações e conhecimentos a respeito do espaço em que vive são constituídos. Da mesma forma, no ambiente escolar ocorrem interações sociais e é, por isso que a prática escolar necessita de um olhar atencioso e crítico sobre as relações que 
ocorrem em tal contexto. Relações essas que interferem positiva ou negativamente no processo de ensino-aprendizagem. Muitas práticas pedagógicas agridem os alunos, sufocando e por vezes, diminuindo no aluno o interesse pela aprendizagem e a vontade de inovar.

Não nos propusemos a investigar o sentido subjetivo de cada participante do espaço escolar tampouco enfatizar aspectos negativos ou positivos dos educadores. Buscamos, por meio dessas experiências, compreender que as relações estabelecidas entre professor-aluno e entre os alunos tem impactos na constituição da subjetividade, nas dimensões individual e social. Ou seja, os sujeitos e os seus espaços de atuação estão permeados de significados, afetos, emoções e de processos simbólicos perceptíveis nas ações, atitudes e posturas. Isso representa uma síntese que imprime um sentido subjetivo nos diferentes processos da vida, como a aprendizagem.

É importante destacar que minha maior dificuldade deu-se pelo fato do meu receio de não realizar julgamentos acerca das pessoas envolvidas. Minhas observações me ajudaram a elucidar que tipo de educador e de educação desejo e pretendo para o presente. É desejável que o educador propicie aos seus alunos oportunidades de aprendizagem e desenvolvimento, respeitando seus desejos, necessidades e interesses.

Consideramos que apenas o conhecimento técnico não é suficiente no processo de ensino-aprendizagem. Do mesmo modo, a crença nas possibilidades de desenvolvimento dos sujeitos desvinculada de atitudes e posturas afirmativas não favorece, por si só, o processo educativo. É fundamental a consciência do educador que deve ser competente, do ponto de vista técnico, e transformador, do ponto de vista humano. 
PARTE III

PERSPECTIVAS PROFISSIONAIS 


\section{PERSPECTIVAS PROFISSIONAIS}

Regozijai-vos na esperança, sede pacientes na tribulação; na oração, perseverantes.

Apóstolo Paulo

Está chegando ao fim um tempo da minha vida que não volta mais: minha primeira graduação. A conclusão desse curso é, para mim, o primeiro passo de uma longa estrada a percorrer.

É hora de rememorar o passado, atuar no presente e planejar ações futuras. É hora de analisar e (re)ler tudo o que foi feito e, por meio dessa leitura com um novo olhar (diferente do que comecei o curso), vejo que muitos são os frutos a colher.

Foram nove semestres entre lágrimas, sorrisos e oração. A garganta aperta, as pernas tremem. Lágrimas pela partida de alguns que conosco começaram essa caminhada, por não aceitarmos injustiças e indiferenças frente a tantos fatos e momentos que passamos na Universidade. Sorrisos a cada conquista ao final do semestre, nos professores que se tornam amigos, aos amigos que tornaram irmãos, a cada conversa informal nos corredores e a celebração à vida que tivemos oportunidade de comemorar juntamente com os amigos. Não podendo esquecer, é claro, de agradecer a Deus por tudo que temos passado, afinal, Ele mesmo nos ensina que devemos dar graças em tudo, pedindo a Ele que nos sustente e nos ajude a ser sempre melhores do achamos que podemos ser. Não para subestimar as pessoas ao nosso redor, mas para acolhê-las e ajudá-las sempre que necessário.

Quando estava cursando o primeiro semestre parecia uma eternidade chegar aqui. Hoje, vejo como passou rápido esse momento tão especial. Vivi muitas coisas, partilhei momentos muito significativos. Aprendi que a prática é muito mais complexa do que a teoria e que muitos não sabe, infelizmente, amar o que fazem. Aprendi que educação é formação e deverá ser sempre progresso e nunca regresso. Aprendi que devemos ser críticos e conscientes, devemos desenvolver, assim também, cidadãos críticos e conscientes, compartilhando vivências e conhecimentos. 
Não posso esquecer, é claro, que o social está muito forte nas minhas escolhas. Ao mesmo tempo em que eu objetivo a formação continuada e a vida acadêmica, decaio sobre a questão da urgente necessidade de segurança e estabilidade que a aprovação em um concurso público pode me proporcionar.

Como projeto de vida profissional, pretendo permanecer no mundo acadêmico, investindo nos meus estudos. Meu objetivo inicial é a Pós-Graduação lato senso em Desenvolvimento Humano, Educação e Inclusão e também em Psicopedagogia Clínica e Institucional.

Inicialmente, pretendo trabalhar em classes inclusivas da Educação Básica, especificamente, Educação Infantil. Objetivo, também, a possibilidade de fazer um Mestrado na área de concentração: Escola, Aprendizagem e Trabalho Pedagógico (EAT). Futuramente, então, pretendo trabalhar como professora universitária e seguir carreira acadêmica. 
Parte IV

REFERÊNCIAS 


\section{REFERÊNCIAS}

BRASIL. Diretrizes Nacionais para a Educação Especial na Educação Básica. Ministério da Educação: Brasília, 2001.

DELORS, Jacques. Os quatro pilares da Educação. In: Um tesouro a Descobrir. UNESCO; MEC. São Paulo: Cortez, 1999.

FELIPPE, Cristiana. Mudando de foco. In: Universo visual: a revista de oftalmologia. Setembro de 2003. Número 10. Disponível na página: http://www.universovisual.com.br/publisher/preview.php?edicao=0903\&id mat=237 Acessado em 11 de novembro de 2007.

FELTRIN, Antonio Efro. Inclusão Social na Escola - Quando a pedagogia se encontra com a diferença. São Paulo: Paulinas, 2004.

FERREIRA, Maria Elisa Caputo; GUIMARÃES, Marly. Educação Inclusiva. Rio de Janeiro: DP\&A Editora, 2003.

FREIRE, Paulo. Pedagogia da autonomia. Rio de Janeiro: Paz e Terra, 1996.

GALVÃO, Izabel. Henri Wallon - Uma Concepção Dialética do Desenvolvimento Infantil. Petrópolis: Vozes, 1995.

GONZÁLEZ REY, Fernando Luis. Psicología e educação: desafios e projeções. In: RAYS, Oswaldo Afonso (Organizador). Trabalho Pedagógico: Realidades e Perspectivas. Porto Alegre: Editora Sulina, 1999.

El Aprendizaje en el Enfoque Histórico-Cultural - Sentido y Aprendizaje. In: TIBALLI, Elianda Figueiredo Arantes e CHAVES, Sandramara Matias (Organizadoras). Concepção e Práticas em Formação de Professores Diferentes Olhares. Editoras: ENDIPE; Alternativa e DP\&A, 2002.

Sujeito e Subjetividade: Uma Aproximação Histórico-Cultural. São Paulo: Pioneira Thomson Learning, 2003.

. O Sujeito, a Subjetividade e o Outro na Dialética Complexa do Desenvolvimento Humano. In: SIMÃO, Lívia Mathias e MARTíNEZ, Albertina Mitjáns (Organizadoras). O Outro no Desenvolvimento Humano. São Paulo: Pioneira Thomson Learning, 2004. p. 1-27.

. O Valor Heurístico da Subjetividade na Investigação Psicológica. In: GONZÁLEZ REY, Fernando Luis (Organizador). Subjetividade, Complexidade e Pesquisa em Psicologia. São Paulo: Pioneira Thomson Learning, 2005. p. 27-51.

O Sujeito que Aprende: Desafios do Desenvolvimento do Tema da Aprendizagem na Psicologia e na Prática Pedagógica. In: TACCA, Maria Carmen V. 
T. (Organizadora). Aprendizagem e Trabalho Pedagógico. Campinas: Alínea, 2006. p. 29-44.

MARTíNEZ, Albertina Mitjáns. A Teoria da Subjetividade de González Rey: Uma Expressão do Paradigma da Complexidade na Psicologia. In: GONZÁLEZ REY, Fernando Luis (Organizador). Subjetividade, Complexidade e Pesquisa em Psicologia. São Paulo: Pioneira Thomson Learning, 2005. p. 1-25.

A perspectiva histórico-cultural da subjetividade: sua significação para o trabalho pedagógico com alunos deficientes. In: Aida Maria Monteiro; MACHADO, Laêda Bezerra; MELO, Márcia Maria de Oliveira e AGUIAR, Maria da Conceição Carrilho de (Organizadoras). Novas subjetividades, currículo, docência e questões pedagógicas na perspectiva da inclusão social. Recife: UFP, 2006, v. 1, p. 371-387.

MIGLIOLI, Cíntia et al. A importância da Afetividade para a Aprendizagem. 1996. Disponível na página: http://www.cpge.aedb.br/arquivos/normal/cintiamiglioli.pdf Acessado em 15 de abril de 2007.

MUNIZ, Cristiano Alberto. Educação e Linguagem. Módulo I - PIE. Brasília: Universidade de Brasília, 2002.

RAPOSO, Patrícia Neves. O Impacto do Sistema de Apoio da Universidade de Brasília na Aprendizagem de Universitários com Deficiência Visual. Brasília, 2006. (Dissertação de Mestrado) Programa de Pós-Graduação da Faculdade de Educação - Universidade de Brasília, Brasília, 2006.

ROSSINI, Maria Augusta Sanches. Pedagogia Afetiva. Petrópolis, RJ: Vozes, 2001.

RUIZ, María Cristina Pérez; MOLINA, Diego Rando; BUENO, María Concepción Toro e LARA, Rafael Torres. In: MARTíN, Manuel Bueno e BUENO, Salvador Toro (Coordenadores). Deficiência Visual: Aspectos Psicoevolutivos e Educativos. São Paulo: Santos Editora Ltda, 2003. p. 45-65.

TACCA, Maria Carmen Villela Rosa. Além de Professor e Aluno: a Alteridade nos Processos de Aprendizagem e Desenvolvimento. In: SIMÃO, Lívia Mathias e MARTíNEZ, Albertina Mitjáns (Organizadoras). O Outro no Desenvolvimento Humano. São Paulo: Pioneira Thomson Learning, 2004. p. 101-130.

- Relação Pedagógica e Desenvolvimento da Subjetividade. In: GONZÁLEZ REY, Fernando Luis (Organizador). Subjetividade, Complexidade e Pesquisa em Psicologia. São Paulo: Pioneira Thomson Learning, 2005. p. 27-51.

Estratégias Pedagógicas: Conceituação e Desdobramentos com o Foco nas Relações Professor-Aluno. . In: TACCA, Maria Carmen Villela Rosa (Organizadora). Aprendizagem e Trabalho Pedagógico. Campinas: Alínea, 2006. p. $45-68$.

TASSONI, Elvira. Afetividade e Aprendizagem: A Relação Professor-Aluno. Reunião anual da ANPED, 2000. Disponível na página: http://www.anped.org.br/reunioes/23/textos/2019t.PDF - Acessado em 15 de abril de 2007. 
TUNES, Elizabeth, TACCA, Maria Carmen Villela Rosa e BARTHOLO JUNIOR, Roberto dos Santos. O professor e $\mathrm{O}$ ato de ensinar. Caderno de Pesquisa, set./dez. 2005, vol.35, №.126, p.689-698. ISSN 0100-1574.

URT, Sônia da Cunha. A Psicologia e a Educação. In: URT, Sônia da Cunha (coordenadora e organizadora) Psicologia e Práticas Educacionais. Campo Grande: Editora UFMS, 2000. Coleção Fontes Novas. p. 16-29.

VIGOTSKI, Lev Semionovitch. Obras Escogidas: Tomo II. Moscou: Editora Pedagógica, 1983.

Obras Completas: Tomo V. Fundamentos da defectologia. La Habana: Pueblo e Educação, 1989. . Psicologia Infantil. In: IV Obras Escogidas. Madrid: Visor, 1996.

. Aprendizagem e desenvolvimento intelectual na idade escolar. In: VIGOTSKI, Lev Semionovitch.; LURIA, Alexandr Romanovich; LEONTIEV, Alexei Nikolaevich. Linguagem, Desenvolvimento e Aprendizagem. São Paulo: Ícone, 2001.

http://portal.mec.gov.br/arquivos/pdf/resolucao2.pdf - Acessado em 30 de outubro de 2007.

http://www.planalto.gov.br/ccivil 03/Leis/L9394.htm - Acessado em 24 de outubro de 2007.

http://www.planalto.gov.br/ccivil 03/ Ato2004-2006/2004/Decreto/D5296.htm Acessado em 24 de outubro de 2007. 


\section{CONSULTADOS}

BARRA JÚNIOR, Bianor Domingues. O Preconceito da Deficiência nas Relações Afetivas: a Constituição Subjetiva de um Deficiente Físico. Brasília, 2005. (Dissertação de Mestrado) Programa de Pós-Graduação da Faculdade de Educação - Universidade de Brasília, Brasília, 2005.

FE. Projeto 4 - Diretrizes. Equipe de Coordenação Pedagógica. FE/UnB.

GONSALVES, Elisa Pereira. Conversas sobre: Iniciação à Pesquisa Científica. $3^{a}$ edição. Campinas: Editora Alínea, 2003.

HOCKENBURY, Don H. e HOCKENBURY, Sandra E. Descobrindo a Psicologia. $1^{\text {a }}$ edição Brasileira. Barueri: Manole Ltda, 2003.

NÓBREGA, Ana Maria; GONSALVES, Elisa Pereira. Fazendo uma Monografia em Educação. Campinas: Editora Alínea, 2005.

OCHAITA, Esperanza e ROSA, Alberto. Percepção, Ação e Conhecimento em Crianças Cegas. In: COLI, César; PALACIOS, Jesús; MARCHESI, Álvaro (Organizadores). Desenvolvimento Psicológico e Educação: Necessidades Educativas Especiais e Aprendizagem Escolar. Volume 3. Porto Alegre: Artes Médicas, 1995. p. 185-199.

RESTREPO, Luis Carlos. O Direito à Ternura. Petrópolis: Vozes, 1998.

http://www.centrorefeducacional.pro.br/vygotsky.html - Acessado em 17 de setembro de 2007.

http://www.entreamigos.com.br/textos/defvisu/inbadev.htm - Acessado em 11 de outubro de 2007.

http://www.ibc.gov.br/ - Acessado em 10 de outubro de 2007.

http://www.saci.org.br/ - Acessado em 11 de outubro de 2007. 